\title{
Arabidopsis CRL4 Complexes: Surveying Chromatin States and Gene Expression
}

\author{
Sandra Fonseca* and Vicente Rubio* \\ Department of Plant Molecular Genetics, Centro Nacional de Biotecnología (CNB-CSIC), Madrid, Spain
}

CULLIN4 (CUL4) RING ligase (CRL4) complexes contain a CUL4 scaffold protein, associated to RBX1 and to DDB1 proteins and have traditionally been associated to protein degradation events. Through DDB1, these complexes can associate with numerous DCAF proteins, which directly interact with specific targets promoting their ubiquitination and subsequent degradation by the proteasome. A characteristic feature of the majority of DCAF proteins that associate with DDB1 is the presence of the DWD motif. DWD-containing proteins sum up to 85 in the plant model species Arabidopsis.

OPEN ACCESS

Edited by:

Myriam Calonje,

Instituto de Bioquímica Vegetal y

Fotosíntesis (IBVF), Spain

Reviewed by:

Jean Molinier,

UPR2357 Institut de biologie moléculaire des plantes (IBMP),

France

Shangwei Zhong,

Peking University, China

*Correspondence:

Sandra Fonseca

sfonseca@cnb.csic.es

Vicente Rubio

vrubio@cnb.csic.es

Specialty section:

This article was submitted to

Plant Physiology,

a section of the journal

Frontiers in Plant Science

Received: 07 June 2019

Accepted: 09 August 2019 Published: 17 September 2019

Citation:

Fonseca S and Rubio V (2019) Arabidopsis CRL4 Complexes: Surveying Chromatin States and

Gene Expression.

Front. Plant Sci. 10:1095. doi: 10.3389/fp/s.2019.01095
In the last decade, numerous Arabidopsis DWD proteins have been studied and their molecular functions uncovered. Independently of whether their association with CRL4 has been confirmed or not, DWD proteins are often found as components of additional multimeric protein complexes that play key roles in essential nuclear events. For most of them, the significance of their complex partnership is still unexplored. Here, we summarize recent findings involving both confirmed and putative CRL4-associated DCAF proteins in regulating nuclei architecture remodelling, DNA damage repair, histone post-translational modification, mRNA processing and export, and ribosome biogenesis, that definitely have an impact in gene expression and de novo protein synthesis. We hypothesized that, by maintaining accurate levels of regulatory proteins through targeted degradation and transcriptional control, CRL4 complexes help to surveil nuclear processes essential for plant development and survival.

Keywords: CRL4, DWD, DCAF, protein degradation, chromatin, transcriptional regulation, ribosome, RNA export

\section{INTRODUCTION}

Proteins participate in every function of a living cell, from metabolic to signalling events, and as cellular structural components. Protein synthesis and degradation are tightly regulated mechanisms that enable precise control of the abundance and function of each particular protein. In the nucleus, the activities of a myriad of proteins converge to maintain and shape chromatin structure and function, which determine gene expression and accumulation of their protein products depending on the cellular and environmental conditions. Chromatin is highly organized and packed into nucleosomes, a compact and stable structure capable of inhibiting transcription, DNA replication, and repair. The nucleosome core is composed of a histone protein octamer around which is wrapped 147 bp of DNA (Luger et al., 1997). Histone post-translational modifications might relax or compact this structure allowing a more efficient progression of polymerases, regulating transcription output and de novo protein synthesis. Concomitantly, tight coordination of transcription with RNA 
processing and export mechanisms is required to ensure the finetuning of cellular protein homeostasis. This requires not only protein synthesis but also refined and highly precise degradation mechanisms. Proteasome-mediated degradation is one of the best-studied mechanisms to terminate protein life cycle and is based in the targeted degradation of ubiquitin-marked proteins. The ubiquitin (Ub) mark is selectively conjugated to protein targets by a conserved enzymatic cascade in which E3 Ub ligases provide the substrate specificity. CULLIN RING ligases (CRLs), the largest class of E3s, represent a family of modular complexes, consisting in eukaryotes of at least seven different cullin scaffold proteins, each of them serving as a building block for the assembly of tens or more multi-subunit CRLs (Deshaies and Joazeiro, 2009). Among this class, CULLIN4 (CUL4) RING ligases (CRL4) control key aspects of cell biology in eukaryotes, including cell cycle progression and DNA damage repair and replication (Jackson and Xiong, 2009; Biedermann and Hellmann, 2011). CUL4 binds RING finger protein (ROC1/RBX1) to recruit the E2 Ub-conjugating enzyme and to DAMAGED DNA BINDING PROTEIN1 (DDB1). The latter functions as a recruiter protein that interacts with DDB1, CUL4ASSOCIATED FACTORS (DCAF) substrate adapters, which recognize specific proteins to target them for ubiquitination and subsequent proteasomal degradation. DCAFs are therefore fundamental to confer substrate specificity to CRL4 complexes (Hu et al., 2004; Bernhardt et al., 2006; Lee et al., 2008).

The observation that, from yeast to animals and plants, CRL4 conserves the capacity to interact with WD40-repeat proteins and the finding that each of these complexes generates functional E3 ligases led to the idea that WD40-repeat containing proteins work as DCAFs (Angers et al., 2006; He et al., 2006). The WD40 repeat spans 40-60 amino acids and is notable for a tryptophanaspartic acid (WD) dipeptide at its $\mathrm{C}$ terminus, but exhibits only limited amino acid sequence conservation (Van Nocker and Ludwig, 2003; Higa and Zhang, 2007). The majority of DCAFs contain six or more WD40 motifs. Each WD40 repeat comprises a four-stranded antiparallel beta sheet that folds as a blade. WD40 blades are organized in a high order structure packed radially around a central axis to form a complete $\beta$-propeller. This structural feature is common to all WD40 proteins whose structure has been determined (Zimmerman et al., 2010). Due to its intrinsic characteristics, the $\beta$-propeller provides multiple surfaces making it prone to protein-protein interaction, and facilitating binding to diverse partners. In fact, WD40 proteins are often integral components of different multiprotein complexes (Zimmerman et al., 2010; Migliori et al., 2012).

DDB1 itself contains three distinct 7-blade $\beta$-propellers (BP), designated BPA, BPB, and BPC (Li et al., 2006). Structural analysis showed that the $\mathrm{BPB}$ domain tethers DDB1 to CUL4, while BPA and BPC form a structurally coupled double propeller pointed away from the CUL4 scaffold, suggesting that DDB1 B-propellers can generate three interaction surfaces that can work independently with different binding specificities. The intrinsic flexibility of this structure would allow accommodating diverse DCAFs with different shapes (Zimmerman et al., 2010). Noteworthy, in Arabidopsis, there are two genes encoding DDB1 proteins, DDB1A and DDB1B. Although their products are $91 \%$ identical they have partially distinct functions and may interact with different DCAF subsets to mediate ubiquitination of specific protein substrates in each case (Schroeder et al., 2002). Additionally, similar to the case of the human DDB1 interaction with the replication licensing factor CDT1, plant DDB1 proteins might also directly interact with certain protein substrates to trigger their destabilization (Hu et al., 2004; McCall et al., 2005).

Analysis of WD40 proteins that interact with DDB1 in animals revealed that a conserved motif within the WD40 repeats is required for this interaction-the DWD motif (also known as WDxR or DxR). This motif is a unique signature in proteins that provides a binding site for DDB1 and consists of 16 amino acids, from which 4 are highly conserved residues: Asp-7 (or Glu), Trp13 (or Tyr), Asp-14 (or Glu), and Arg-16 (or Lys) (He et al., 2006; Lee et al., 2008).

In silico analysis has shown that the DWD protein family was in expansion during viridiplantae evolution (Tevatia and Oyler, 2018). Indeed, a large number of DWD proteins have been identified in Arabidopsis (85), rice (Oryza sativa; 78), and soybean (Glycine max; 161) (Lee et al., 2008; Bian et al., 2017). In the last decade, great advances have been made on the characterization of the molecular functions of DWD proteins as part of CRL4 and other multimeric complexes. From the 85 DWD Arabidopsis proteins described by Lee and co-workers in 2008, 53 have been at least partially characterized and 32 of those have an impact in chromatin homeostasis, transcriptional regulation, and de novo protein synthesis (Table 1; Supplementary Table 1). These proteins, together with the DDB1-associated CDDD module, involved in surveying chromatin states and gene expression as part of CRL4 complexes are the focus of this review (Figure 1).

\section{NUCLEAR STRUCTURE AND LIGHT AS A SIGNAL}

Plants use light as an informational cue to control a multitude of physiological responses throughout their life cycle. Thus, light affects multiple aspects of plant development, including seed germination, seedling and leaf development, shade avoidance responses, and flowering (Jiao et al., 2007). Collectively, these responses are known as photomorphogenesis, which represents one of the best-studied developmental processes in plants (Kendrick and Kronenberg, 2012). Light perception and signalling are tightly regulated by components of the ubiquitinproteasome system (the so-called COP/DET/FUS proteins), which modulate the stability and activity of both photoreceptors and transcriptional regulators (i.e., bZIP transcription factor ELONGATED HYPOCOTYL 5, HY5). In this process, DWDcontaining CONSTITUTIVE PHOTOMORPHOGENIC1 (COP1) and SUPPRESSOR OF PHYA (SPA 1-4) proteins play a central role acting as part of CRL4 E3 Ub ligases that target a wide variety of photomorphogenesis promoting factors, including HY5, the photoreceptor PhyA, and the flowering time regulator CONSTANS (CO) in Arabidopsis (Lau and Deng, 2012).

$\mathrm{COP} / \mathrm{DET} / \mathrm{FUS}$ proteins include additional DCAF proteins that lack any WD40 repeats, but they associate to CRL4 complexes by physical binding to DDB1. In Arabidopsis, 


\begin{tabular}{|c|c|c|c|c|c|c|}
\hline AGI & GENE NAME & $\begin{array}{l}\text { DWD } \\
\text { Present }\end{array}$ & $\begin{array}{l}\text { Associates } \\
\text { with DDB1 }\end{array}$ & Molecular Function & $\begin{array}{l}\text { Other interactors related } \\
\text { with chromatin and/or gene } \\
\text { expression }\end{array}$ & References \\
\hline \multicolumn{7}{|c|}{ NUCLEAR ARCHITECTURE AND LIGHT SIGNALLING } \\
\hline AT2G32950 & $\begin{array}{l}\text { COP1 (CONSTITUTIVE } \\
\text { PHOTOMORPHOGENIC 1) }\end{array}$ & yes & yes & $\begin{array}{l}\text { CRL4 E3 ligase activity; light signalling; } \\
\text { photomorphogenesis; nuclear architecture; } \\
\text { flowering; others. }\end{array}$ & $\begin{array}{l}\text { COP1-SPA complex } \\
\text { Targets TFs as HY5, HFR1, CO } \\
\text { and others }\end{array}$ & $\begin{array}{l}\text { Ang et al., 1998; Osterlund et al., 2000; } \\
\text { Jang et al., 2005; Liu et al., 2008; Bourbousse } \\
\text { et al., } 2015\end{array}$ \\
\hline AT2G46340 & $\begin{array}{l}\text { SPA1 (SUPPRESSOR OF } \\
\text { PhyA 1) }\end{array}$ & yes & yes & $\begin{array}{l}\text { CRL4 E3 ligase activity; light signalling; } \\
\text { photomorphogenesis; flowering }\end{array}$ & COP1-SPA complex & $\begin{array}{l}\text { Hoecker et al., 1999; Saijo et al., 2003; } \\
\text { Chen et al., } 2010\end{array}$ \\
\hline AT4G11110 & SPA2 & yes & yes & $\begin{array}{l}\text { Light signalling; photomorphogenesis; } \\
\text { flowering }\end{array}$ & COP1-SPA complex & $\begin{array}{l}\text { Laubinger and Hoecker, 2003; Laubinger et al., } \\
\text { 2006; Chen et al., } 2010\end{array}$ \\
\hline AT3G15354 & SPA3 & yes & yes & $\begin{array}{l}\text { Light signalling; photomorphogenesis; } \\
\text { flowering }\end{array}$ & COP1-SPA complex & $\begin{array}{l}\text { Laubinger and Hoecker, 2003; Laubinger et al., } \\
\text { 2006; Chen et al., } 2010\end{array}$ \\
\hline AT1G53090 & SPA4 & yes & yes & $\begin{array}{l}\text { Light signalling; photomorphogenesis; } \\
\text { flowering }\end{array}$ & COP1-SPA complex & $\begin{array}{l}\text { Laubinger and Hoecker, 2003; } \\
\text { Laubinger et al., 2006; Chen et al., } 2010\end{array}$ \\
\hline AT4G10180 & DET1 (DE-ETIOLATED 1) & no & yes & $\begin{array}{l}\text { Light signalling; photomorphogenesis; } \\
\text { nuclear architecture; co-transcriptional } \\
\text { repressor in circadian clock }\end{array}$ & $\begin{array}{l}\text { CDDD complex; PIF1-4, LHY, } \\
\text { HFR1 transcription factors; } \\
\text { others }\end{array}$ & $\begin{array}{l}\text { Pepper et al., 1994; Osterlund et al., 2000; } \\
\text { Bernhardt et al., 2006; Lau et al., 2011; } \\
\text { Dong et al., 2014; Bourbousse et al., 2015; } \\
\text { Shi et al., } 2015\end{array}$ \\
\hline AT3G13550 & $\begin{array}{l}\text { COP10 (CONSTITUTIVE } \\
\text { PHOTOMORPHOGENIC 10) }\end{array}$ & no & yes & $\begin{array}{l}\text { Ubiquitin ligase, enhancer of other ubiquitin } \\
\text { ligases; photomorphogenesis }\end{array}$ & CDDD complex & Yanagawa et al., 2004; Lau and Deng, 2009 \\
\hline AT5G52250 & $\begin{array}{l}\text { RUP1 (REPRESSOR OF UVB- } \\
\text { PHOTOMORPHOGENESIS 1) }\end{array}$ & yes & nd & CRL4 E3 ligase activity; UV-B signalling & UVR8 & Gruber et al., 2010; Heijde and UIm, 2013 \\
\hline AT5G23730 & RUP2 & yes & nd & CRL4 E3 ligase activity; UV-B signalling & UVR8 & Gruber et al., 2010; Heijde and UIm, 2013 \\
\hline AT4G34280 & $\begin{array}{l}\text { DHU1 (DWD } \\
\text { HYPERSENSITIVE TO UV-B 1) }\end{array}$ & yes & yes & UV-B signalling & COP1, RUP1 & Kim et al., 2014; Kim et al., 2017 \\
\hline \multicolumn{7}{|c|}{ DNA DAMAGE REPAIR } \\
\hline AT1G27840 & $\begin{array}{l}\text { CSA-1 (COCKAYNE } \\
\text { SYNDROME A) }\end{array}$ & yes & yes & $\begin{array}{l}\text { CRL4 E3 ligase activity; nuclear excision } \\
\text { repair; UV-B tolerance; genomic integrity }\end{array}$ & CSA heterotetramer & Zhang et al., 2010 \\
\hline AT5G58760 & $\begin{array}{l}\text { DDB2 (DNA BINDING } \\
\text { PROTEIN 2) }\end{array}$ & yes & yes & $\begin{array}{l}\text { CRL4 E3 ligase activity; nuclear excision } \\
\text { repair; UV-B tolerance and genomic integrity }\end{array}$ & nd & Koga et al., 2006; Molinier et al., 2008 \\
\hline AT5G41560 & DDA1 (DDB1-ASSOCIATED 1) & no & yes & $\begin{array}{l}\text { H2B ubiquitination; } \\
\text { ABA signalling }\end{array}$ & CDDD complex; Targets SGF11 & Irigoyen et al., 2014; Nassrallah et al., 2018 \\
\hline AT4G10180 & DET1 & no & yes & DNA damage repair & & Castells et al., 2010 \\
\hline \multicolumn{7}{|c|}{ HISTONE AND DNA MARKS } \\
\hline AT5G58230 & $\begin{array}{l}\text { MSI1 (MULTICOPY } \\
\text { SUPPRESSOR OF IRA1) }\end{array}$ & yes & yes & $\begin{array}{l}\text { H3K27me3; parental imprinting; embryo } \\
\text { development; cell cycle control }\end{array}$ & $\begin{array}{l}\text { PRC2 (POLYCOMB REPRESSIVE } \\
\text { COMPLEX 2) }\end{array}$ & Dumbliauskas et al., 2011 \\
\hline AT2G16780 & MSI2 & yes & nd & unknown & nd & Lee et al., 2008 \\
\hline AT4G35050 & MSI3 & yes & yes & unknown & nd & Pazhouhandeh et al., 2011 \\
\hline AT2G19520 & MSI4 & & yes & H3K27me3; flowering time regulation & PRC2 & Pazhouhandeh et al., 2011 \\
\hline AT4G10180 & DET1 & no & yes & $\begin{array}{l}\text { H2B ubiquitination, } \\
\text { Regulates } \mathrm{H} 3 \mathrm{~K} 9 \text { acetylation }\end{array}$ & $\begin{array}{l}\text { Targets SGF11 and UBP22, part } \\
\text { of the DUBm (deubiquitination } \\
\text { module) }\end{array}$ & $\begin{array}{l}\text { Benvenuto et al., 2002; } \\
\text { Nassrallah et al., 2018; } \\
\text { Guo et al., } 2008\end{array}$ \\
\hline AT2G32950 & COP1 & yes & yes & Regulates H3K9 acetylation & & Guo et al., 2008 \\
\hline AT5G14530 & S2La (SWD2-LIKE A) & yes & nd & Flowering time regulation & nd & $\begin{array}{l}\text { Fiorucci et al., 2019; } \\
\text { Kapolas et al., } 2016\end{array}$ \\
\hline AT5G66240 & S2Lb & yes & yes & $\begin{array}{l}\text { H3K4me3; cell wall thickening; anther } \\
\text { dehiscence }\end{array}$ & $\begin{array}{l}\text { COMPASS (COMPlex of Proteins } \\
\text { Associated with Set1) }\end{array}$ & Beris et al., 2016; Fiorucci et al., 2019 \\
\hline
\end{tabular}


TABLE 1 | Continued

\begin{tabular}{|c|c|c|c|c|c|c|}
\hline AGI & GENE NAME & $\begin{array}{l}\text { DWD } \\
\text { Present }\end{array}$ & $\begin{array}{l}\text { Associates } \\
\text { with DDB1 }\end{array}$ & Molecular Function & $\begin{array}{l}\text { Other interactors related } \\
\text { with chromatin and/or gene } \\
\text { expression }\end{array}$ & References \\
\hline AT5G67320 & $\begin{array}{l}\text { HOS15 (HIGH EXPRESSION } \\
\text { OF OSMOTICALLY } \\
\text { RESPONSIVE GENES 15) }\end{array}$ & yes & yes & $\begin{array}{l}\text { CRL4 E3 ligase activity; regulates histone } \\
\text { acetylation; cold tolerance and response to } \\
\text { abiotic stresses }\end{array}$ & $\begin{array}{l}\text { HD2C; CBFs; Conforms the } \\
\text { HOS15-HDA9-PWR complex }\end{array}$ & $\begin{array}{l}\text { Park et al., 2018a; Park et al., 2018b; Zhu D. } \\
\text { et al., 2008; Suzuki et al., 2018; Mayer et al., } \\
2019\end{array}$ \\
\hline \multicolumn{7}{|c|}{ mRNA PROCESSING AND EXPORT } \\
\hline AT5G13480 & FY (FLOWERING LOCUS Y) & yes & yes & $\begin{array}{l}\text { Control of flowering; alternative } \\
\text { polyadenylation; embryo development }\end{array}$ & FCA & $\begin{array}{l}\text { Lee et al., 2008; Shi et al., 2009; Simpson et al., } \\
2003\end{array}$ \\
\hline AT1G73720 & $\begin{array}{l}\text { SMU1 (SUPRESSOR OF } \\
\text { MEC-8 AND UNC-52 1) }\end{array}$ & yes & nd & Alternative splicing & Spliceosome & Kanno et al., 2017 \\
\hline AT5G56130 & $\begin{array}{l}\text { TEX1/THO3 (TANSCRIPTION } \\
\text { EXPORT 1) }\end{array}$ & yes & nd & $\begin{array}{l}\text { mRNA export from nucleus; siRNA } \\
\text { biosynthesis }\end{array}$ & TREX/THO complex & $\begin{array}{l}\text { Lee et al., 2010; Yelina et al., 2010; Jauvion et al., } \\
\text { 2010; Sørensen et al., } 2017\end{array}$ \\
\hline AT2G19430 & THO6 & yes & yes & $\begin{array}{l}\text { mRNA export from nucleus; siRNA } \\
\text { biosynthesis; ABA signaling; Conforms a } \\
\text { functional CRL4 E3 ligase }\end{array}$ & TREX/THO complex & $\begin{array}{l}\text { Lee et al., 2010; Yelina et al., 2010; Jauvion et al., } \\
\text { 2010; Sørensen et al., } 2017\end{array}$ \\
\hline AT1G80670 & $\begin{array}{l}\text { RAE1 (RNA EXPORT } \\
\text { FACTOR 1) }\end{array}$ & yes & yes & $\begin{array}{l}\text { mRNA export; shuttling at the nuclear } \\
\text { envelope }\end{array}$ & Nuclear pore complex & $\begin{array}{l}\text { Lee et al., 2008; Pritchard et al., 1999; } \\
\text { Okamura et al., } 2015 .\end{array}$ \\
\hline \multicolumn{7}{|c|}{ miRNA BIOGENESIS } \\
\hline AT4G15900 & $\begin{array}{l}\text { PRL1 (PLEIOTROPIC } \\
\text { REGULATORY LOCUS 1) }\end{array}$ & yes & yes & $\begin{array}{l}\text { miRNA biogenesis; CRL4 E3 ubiquitin ligase } \\
\text { activity; energy homeostasis; plant innate } \\
\text { immunity }\end{array}$ & $\begin{array}{l}\text { MAC complex (MOS4-Associated } \\
\text { Complex); Targets AKIN10 kinase }\end{array}$ & $\begin{array}{l}\text { Lee et al., 2008; Monaghan et al., 2009; } \\
\text { Jia et al., 2017; Li et al., 2018; Wiborg et al., } \\
2008\end{array}$ \\
\hline AT3G16650 & PRL2 & yes & nd & miRNA biogenesis & MAC complex & Jia et al., 2017; Li et al., 2018 \\
\hline AT2G33340 & МАСЗВ & yes & nd & $\begin{array}{l}\text { miRNA biogenesis; } \\
\text { CRL4 E3 ubiquitin ligase activity; plant innate } \\
\text { immunity }\end{array}$ & MAC complex & $\begin{array}{l}\text { Jia et al., } 2017 \text {; } \\
\text { Li et al., } 2018\end{array}$ \\
\hline \multicolumn{7}{|c|}{ RIBOSOME BIOGENESIS } \\
\hline AT2G47990 & SWA1 (SLOW WALKER 1) & yes & nd & $\begin{array}{l}18 \mathrm{~S} \text { rRNA processing; mitotic progression; } \\
\text { megagametogenesis }\end{array}$ & nd & Shi et al., 2005 \\
\hline AT1G15440 & $\begin{array}{l}\text { PWP2 (PERIODIC } \\
\text { TRYPTOPHAN PROTEIN 2) }\end{array}$ & yes & nd & $\begin{array}{l}\text { 18S rRNA processing; gametophyte and } \\
\text { embryo sac development }\end{array}$ & nd & Missbach et al., 2013 \\
\hline AT4G05410 & YAO (YAOZHE) & yes & no & $\begin{array}{l}18 \mathrm{~S} \text { rRNA processing; male and female } \\
\text { gametogenesis; zygote development; cell } \\
\text { division }\end{array}$ & nd & Li et al., 2010 \\
\hline AT4G21130 & EMB2271 & yes & nd & $18 \mathrm{~S}$ rRNA processing & nd & Li et al., 2010 \\
\hline AT5G15550 & $\begin{array}{l}\text { PEP2 (PESCADILLO } \\
\text { ORTHOLOG 2) }\end{array}$ & yes & nd & $\begin{array}{l}28 \mathrm{~S} \text { and } 5.8 \mathrm{~S} \text { rRNA processing; cell } \\
\text { proliferation; cell cycle }\end{array}$ & $\begin{array}{l}\text { PeBoW (PES, BOP, WDR12) } \\
\text { complex }\end{array}$ & Zografidis et al., 2014; Ahn et al., 2016 \\
\hline AT5G52820 & NLE (NOTCHLESS) & yes & nd & $\begin{array}{l}60 \text { S ribosomal subunit maturation and } \\
\text { assembly; cell growth and proliferation; } \\
\text { female gametophyte development }\end{array}$ & & $\begin{array}{l}\text { Chantha and Matton, 2007; Chantha et al., } \\
2010\end{array}$ \\
\hline
\end{tabular}

The table summarizes protein function information within the scope of chromatin remodeling and additional nuclear events that affect gene expression. nd stands for non-determined. 
the most prominent representative is DE-ETIOLATED1 (DET1), a classic photomorphogenesis repressor (Pepper et al., 1994). In addition to DDB1, DET1 associates with COP10 and DET1, DDB1-ASSOCIATED1 (DDA1), both also non WD-40 proteins, to form a heterotetrameric CDDD module that binds to CUL4 (Schroeder et al., 2002; Yanagawa et al., 2004; Pick et al., 2007; Biedermann and Hellmann, 2011; Chen et al., 2006, Irigoyen et al., 2014). DET1 acts at different levels to repress photomorphogenesis during plant development. Thus, during seedling establishment in the dark, DET1 facilitates CRL4COP1-SPA activity when promoting HY5 destabilization, although the molecular details of DET1 function in this regard are unknown (Osterlund et al., 2000). In addition, DET1 directly interacts and stabilizes basic helix-loop-helix PHYTOCHROME INTERACTING FACTORS (PIFs) transcription factors, which trigger transcriptional responses under dark conditions, but act as transcriptional co-repressor in circadian rhythms (Lau et al., 2011; Dong et al., 2014). In the case of light-regulated seed germination, DET1, together with COP10, assembles into CRL4DET1-COP10 complexes that bind PIF1, increasing its stability and activity in the dark to repress germination. Additionally, CRL4-DET1-COP10 target LONG HYPOCOTYL IN FARRED 1 (HFR1) protein for proteasomal degradation under dark conditions. HFR1 is a positive regulator of seed germination that forms heterodimers with PIF1, impeding PIF1 ability to bind to its target genes. By acting on different downstream effectors, DET1 becomes a central repressor of light-induced seed germination (Shi et al., 2015).

Recent work by Bourbousse et al., 2015, showed that both Arabidopsis DET1 and COP1 also regulate shaping of nuclear architecture in response to the light conditions. Thus, in etiolated cotyledons, DET1 and COP1 maintain heterochromatin in a decondensed state. Upon light exposure, cryptochrome-dependent light signalling releases nucleus expansion and large-scale heterochromatin condensation, likely by inhibiting COP1 and DET1 function. These global nuclear phenotypes correlate with RNA Polymerase II (RNAPII) transcriptional activity and may also impact gene silencing efficiency (Bourbousse et al., 2015). Although the molecular details of COP1 and DET1 function in these processes are still unknown, it is striking that both CRL4-associated proteins affect high order nuclear dynamics. Whether they participate in the same light-dependent regulatory mechanisms or in different additive ones needs to be unveiled.

Still regarding light perception, the UV RESISTANCE LOCUS 8 (UVR8) is also a $\beta$-propeller protein with seven blade-shaped $\beta$-sheets that acts as an UV-B photoreceptor in Arabidopsis (Rizzini et al., 2011). UVR8 has homology to human Regulator of Chromatin Condensation 1 (RCC1), which associates to chromatin by directly interacting with histones (Kliebenstein et al., 2002; Cloix and Jenkins, 2008). Though UVR8 physical association to chromatin is controversial (Binkert et al., 2016), it directly binds COP1 in a UV-dependent manner to protect HY5 against proteasomal degradation and to enhance HY5 gene expression. Therefore, increased HY5 activity confers UV acclimation and protection to plants (Favory et al., 2009; Oravecz et al., 2006). Despite the fact that UVR8 does not contain a DWD motif, its activity is repressed by two redundant DWD proteins, REPRESSOR OF UV-B PHOTOMORPHOGENESIS 1 (RUP1) and RUP2. Thus, RUP1 and RUP2 induce photomorphogenesis by directly interacting with UVR8, mediating its dimerization and disrupting UVR8COP1 interaction, which halts UV-B signalling (Gruber et al., 2010; Heijde and Ulm, 2013). Another DWD protein, DWD HYPERSENSITIVE TO UV-B 1 (DHU1), also contributes to repression of the UV-B signal transduction pathway by interfering with COP1 function. DHU1 likely works in association with RUP1 and is able to bind DDB1, suggesting a role as a substrate adapter for CRL4 complexes (Kim et al., 2017; Kim et al., 2014).

\section{DNA LESION DETECTION AND REPAIR - LIGHT AS A DAMAGE}

Plants use sunlight for photosynthesis and therefore cannot avoid constant exposure to solar UV radiation. To cope with the adverse effects of UV light, plants accumulate photoprotective pigments, such as flavonoids (i.e., anthocyanins) and carotenoids, and have evolved DNA damage repair mechanisms, such as photoreactivation and dark repair pathways (Stapleton and Walbot, 1994; Rozema et al., 2002; Kimura et al., 2004). In Arabidopsis, HY5 is a major regulator of anthocyanin accumulation in response to light (Ang and Deng, 1994). Therefore, production of the photoprotective pigment shield largely depends on the activity of COP1- and DET1-containing CRL4 E3 Ub ligases that promote HY5 destabilization (Holm et al., 2002). In the green algae Chlamydomonas reinhardtii, DET1 and DDB1 also repress photoprotective responses by regulating blue light-mediated induction of LIGHT-HARVESTING COMPLEX STRESS-RELATED PROTEINS 1 and 3 genes, necessary for the dissipation of energy under high-light conditions (Aihara et al., 2019).

DNA repair mechanisms are essential for the survival of organisms since, if efficient repair of damaged DNA does not take place, genome integrity is at risk (Ries et al., 2000). In humans, unrepaired lesions might potentially introduce oncogenic mutations and are a major cause of skin carcinogenesis (Hoeijmakers, 2009). Among the lesions caused by UV light, cyclobutane pyrimidine dimers (CPDs) and pyrimidine (6-4) pyrimidinone dimers (6-4PPs) are the most common ones, accounting for $75 \%$ and $25 \%$ of DNA lesions, respectively, being able to stall RNAPII during transcription, which largely alters gene expression and cell functions (Mitchell et al., 1989; Fischer et al., 2011). Contrary to photoreactivation, dark repair pathways do not directly reverse DNA damage, but instead replace the damaged DNA with new, undamaged nucleotides. Dark repair mechanisms include the nucleotide excision repair (NER), base excision repair (BER), and mismatch repair (MMR) pathways (Scrima et al., 2011). DDB1 was initially identified as a damaged DNA binding protein that heterodimerizes with two DWDcontaining proteins, Damage-specific DNA Binding protein 2 (DDB2) and Cockayne Syndrome A (CSA), that control different NER pathways, global genome repair (GGR) and transcriptioncoupled repair (TCR), respectively (Lee and Zhou, 2007; 
Shuck et al., 2008). Mutations in CSA and DDB2 result in hereditary diseases, termed Xeroderma pigmentosum and Cockayne syndrome, characterized by cutaneous hypersensitivity to sunlight exposure and high susceptibility to UV-induced skin cancer, respectively (Lee and Zhou, 2007; Jackson and Xiong, 2009). Though they act through specific pathways, both CRL4DDB2 and CRL4-CSA share common architectural features and a common mechanism of activation by CSN displacement from the CRL4-DCAF upon substrate binding to the DCAF (Fischer et al., 2011).

DDB2 and CSA function as part of CRL4 complexes that are conserved in plants (Biedermann and Hellmann, 2010). Thus, Arabidopsis $d d b 2$ mutants display enhanced sensitivity to UV irradiation, methyl methanesulfonate, and $\mathrm{H}_{2} \mathrm{O}_{2}$ stress (Koga et al., 2006) while overexpression of DDB1A increases plant tolerance to UV (Al Khateeb and Schroeder, 2009). Moreover, DDB2 associates with the CUL4-DDB1A complex to form an E3 ligase that modulates NER DNA damage repair (GGR associated) upon UV stress (Molinier et al., 2008). CSAat1A, a CSA-like gene, was identified in a forward screening for mutants with altered DNA damage responses. In Arabidopsis, there are two CSA-like genes that form heterotetramers within active CRL4 E3 ligases to enable plant responses to UV-B irradiation (Zhang et al., 2010).

The CDDD complex seems to be also essential for damage DNA repair processes in plants. Thus, it has been reported that an appropriate dosage of DET1 is necessary for efficient removal of UV photoproducts through the NER (GGR-type) pathway in Arabidopsis. In this context, DET1 is required for the CRL4-dependent degradation of DDB2 in order to complete the DNA repair process. Upon UV irradiation, DET1 is degraded concomitantly with DDB2, likely as a means to limit the activity of CUL4-DDB1-DET1-DDB2 complexes (Castells et al., 2011).

Similarly, DDA1 has been involved in the response to DNA damage in mammalian systems. Thus, dda1 depleted human cells spontaneously accumulated double strand DNA breaks (Olma et al., 2009). Moreover, recent studies identify DDA1 as an oncogene in various types of cancers and it is being considered as a therapeutic target (Cheng et al., 2017; Zhao et al., 2016; Gao et al., 2017). Recent structural data has shown that the 19 N-terminal amino acids of DDA1 adopt a partially coiled conformation that docks on a groove at the bottom surface of the DDB1 BPA domain. The authors hypothesized that the flexible C-terminal region of DDA1 might be able to reach DCAF or even DCAF-bound substrates to either facilitate recruitment of targets or modulate the overall topology of the fully assembled CRL4-target complex. These functions might be required for proper activation of CRL4 machineries during DNA damage responses (Shabek et al., 2018).

Despite the conservation of CRL4 machineries involved in NER in higher eukaryotes, photoreactivation, which is mediated by photolyases, is thought to be the major DNA repair pathway for CPDs and 6-4 PPs lesions in higher plants. Photolyases can specifically bind to these DNA lesions and remove them directly by absorbing energy (Molinier, 2017). Photoreactivation and photolyases have been reported in several plant species but are also common for many other organisms (Molinier, 2017; Kimura et al., 2004). Interestingly, Arabidopsis det1 mutants display over-expression of DNA photolyase genes promoted by higher levels of $\mathrm{HY} 5 / \mathrm{HYH}$, resulting in increased sunscreen effect and greater tolerance to UV-C irradiation (Castells et al., 2010). Therefore, DET1, likely as part of CRL4-CDDD complexes, participates in different pathways leading to DNA protection and repair against UV light while being itself a repressor of light signalling. Whether regulatory relationships exist between DET1 functions in these two pathways should be addressed in future studies.

\section{REGULATION OF HISTONE AND DNA MARKS}

Histone post-translational modifications (PTM) regulate chromatin accessibility and gene expression. A plethora of protein complexes tightly regulate the conjugation of activating or inactivating marks to histones facilitating or constraining the accessibility of transcription-complexes to specific genomic regions. Genetic and molecular evidence have shown that CRL4 play major roles in this process in Arabidopsis. Thus, CUL4-DDB1 complexes are known to interact with DWD protein MULTICOPY SUPPRESSOR OF IRA1 (MSI1), which is also an integral part of the evolutionary conserved POLYCOMB REPRESSIVE COMPLEX 2 (PRC2) that catalyses H3K27 trimethylation, a repressive histone mark (Dumbliauskas et al., 2011). Mutation of CUL4 leads to autonomous endosperm development and loss of parental MEDEA imprinting, which is essential for seed formation, supporting a functional link between CRL4 and the PRC2 complex (Dumbliauskas et al., 2011). CRL4 also interacts with MSI4, which represses FLC expression through its association with PRC2. Thus, the lack of MSI4 or decreased CUL4 activity reduces $\mathrm{H} 3 \mathrm{~K} 27$ trimethylation on FLC, but also on its downstream target $F T$, resulting in increased expression of both genes during the regulation of flowering timing in Arabidopsis (Pazhouhandeh et al., 2011). In this context, it would be interesting to determine to which extent CRL4 function aids PRC2 activity and whether CRL4 ubiquitination activity is relevant for turnover of any PRC2 component as a means to modulate its gene repressor activity according to specific developmental or environmental conditions.

Non-DWD proteins that associate with DDB1 have been also shown to be key in integrating environmental cues to shape the Arabidopsis epigenome landscape, as recently shown for DET1 (Nassrallah et al., 2018). The idea that DET1 can act as a transcriptional repressor originally came with the finding that it has the capacity to directly interact with Histone 2B (H2B), more specifically with non-acetylated tails of $\mathrm{H} 2 \mathrm{~B}$, which means that its interaction correlates with histone states compatible with transcriptional repression (Benvenuto et al., 2002). Recently, the significance of this interaction has been unveiled, since DET1 and the CDDD complex influence histone $\mathrm{H} 2 \mathrm{~B}$ monoubiquitination ( $\mathrm{H} 2 \mathrm{Bub}$ ), a chromatin mark occurring over gene bodies that promotes light-dependent gene activation (Bourbousse et al., 2012; 
Nassrallah et al., 2018). Thus, it was found that the CDDD subunit DDA1 directly interacts with SAGA-INTERACTING FACTOR (SGF11), which, together with UBIQUITIN PROTEASE (UBP22) and ENHACER OF YELLOW2 (ENY2), comprise the Arabidopsis SAGA deubiquitination module (DUBm). Recognition of SGF11 by DDA1 recruits the CRL4-CDDD module to ubiquitinate and degrade the DUBm in a DET1 - and dark- dependent manner. Therefore, Arabidopsis det 1 mutants display reduced levels of $\mathrm{H} 2 \mathrm{Bub}$ mark as a consequence of the accumulation of DUBm and increased $\mathrm{H} 2 \mathrm{Bub}$ deubiquitination activity (Nassrallah et al., 2018). Noticeably, det1 mutants displayed altered accumulation of several other histone marks related with transcription activation, although the molecular mechanisms by which DET1 governs their accumulation and distribution over the genome are unknown (Nassrallah et al., 2018). In agreement with these findings, DET1 and COP1 had been previously shown to repress accumulation of the gene activating mark $\mathrm{H} 3 \mathrm{~K} 9 \mathrm{ac}$ at specific loci. Thus, Arabidopsis det 1 and cop 1 mutants displayed increased $\mathrm{H} 3 \mathrm{~K} 9 \mathrm{ac}$ levels in light regulated genes that correlated with their enhanced transcription levels. However the molecular basis underlying these phenotypes is still unknown (Guo et al., 2008).

Interestingly, Arabidopsis CDDD subunit COP10, which corresponds to an E2 Ub variant (i.e., lacks the cysteine residue at the catalytic centre required for Ub conjugation), has been shown to enhance the Ub binding activity of genuine E2 enzymes in vitro, including UBIQUITIN CONJUGATING ENZYME 1 (UBC1) and UBC2 (Yanagawa et al., 2004; Lau and Deng, 2009). The latter act in coordination with E3 Ub ligases HISTONE UBIQUITINASE 1 (HUB1) and HUB2 to ubiquitinate H2B (Xu et al., 2009). These findings suggest that COP10, and by extent the CRL4-CDDD, might modulate both $\mathrm{H} 2 \mathrm{~B}$ ubiquitination and deubiquitination.

$\mathrm{H} 2 \mathrm{Bub}$ promotion of $\mathrm{H} 3 \mathrm{~K} 4 \mathrm{me} 3$ deposition on actively transcribed genes is among the best studied trans-histone crosstalk in yeast and metazoans (Sun and Allis, 2002; Kim et al., 2009). In yeast, SET1 histone methyltransferase (HMT) catalyzes $\mathrm{H} 3 \mathrm{~K} 4 \mathrm{me} 3$ deposition acting as part of the COMPASS (COMPlex of Proteins Associated with Set1), which also contains the WD40 repeat-containing proteins Swd1, Swd2, Swd3, among others (Schuettengruber et al., 2017). In Arabidopsis, the most relevant HMT in COMPASS is SDG2 (SET DOMAIN GROUP2). Recently, DWD-containing proteins SWD2-like a and b (S2La, S2Lb) were identified as the plant homologs of the Swd2 yeast protein. Together with SDG2, S2Lb directly influence H3K4me3 enrichment over highly transcribed genes, similar to its yeast ortholog. However, in Arabidopsis, $\mathrm{H} 3 \mathrm{~K} 4 \mathrm{me} 3$ deposition seems not to rely in a trans-histone crosstalk with H2Bub (Fiorucci et al., 2019). In Arabidopsis, S2Lb was found to directly interacts with DDB1, indicating it might form part of CRL4 E3 Ub ligases (Beris et al., 2016). S2Lb also co-purifies with the AtCOMPASS core subunit WDR5a, also a WD40 protein. Interestingly, it has been shown that, in neuronal cells, CUL4B complexes can target WDR5 protein for degradation (Nakagawa and Xiong, 2011). Whether this mechanism is conserved in plants needs to be explored.
HIGH EXPRESSION OF OSMOTICALLY RESPONSIVE GENES 15 (HOS15), a DWD-repeat protein involved in cold tolerance, regulates the acetylation levels of cold responsive genes by targeting HISTONE DEACETYLASE 2C (HD2C) in a cold-dependent manner. This degradation is mediated by the CRL4 complex in which HOS15 acts as a substrate receptor (Park et al., 2018b). HOS15 can also directly interact with CBF transcription factors to modulate cold-induced binding to cold responsive gene promoters and promote the acquisition of cold tolerance (Zhu J. et al., 2008; Park et al., 2018b). Recently, it has been demonstrated that HOS15 is also a core component of the Arabidopsis HISTONE DEACETYLASE9-POWERDRESS (HDA9-PWR) complex (Suzuki et al., 2018; Mayer et al., 2019). hos 15 mutants display histone hyperacetylation similar to those of $h d a 9$ and pwr mutants and ninety percent of HOS15-regulated genes are also controlled by HDA9 and PWR, being the majority of these genes stress-related (Mayer et al., 2019). In addition, HOS15 regulates HDA9 protein accumulation in the nucleus and its association to chromatin but does not affect the overall HDA9 protein stability (Mayer et al., 2019; Park et al., 2018a). Moreover, the HOS15-HDA9 module can directly interact with the Evening complex to reduce histone acetylation levels at the promoter of flowering activator GIGANTEA (GI). Therefore, the HOS15-HDA9 module could regulate photoperiodic flowering via transcriptional repression of GI (Park et al., 2019). Besides its interaction with HD2C, HDA9, and PWR, HOS15 was found to associate in affinity purification assays with other Histone deacetylases and Histones H1.2 variant, H2B and H4 (Park et al., 2018a; Zhu J. et al., 2008).

Altogether, these evidences indicate that DCAF proteins can affect histone posttranslational modification, either indirectly, by regulating the stability or activity of proteins or complexes that mediate deposition of histone marks, or directly, by acting as core components of such histone-modifying machineries.

Finally, recent studies suggest that the COP9 signalosome (CSN), a key regulator of CULLIN-based E3 Ub ligases, including CRL4, regulates DNA methylation in Arabidopsis (Tuller et al., 2018). The CSN consists of eight subunits (CSN1-8) and is highly conserved in eukaryotes. CSN was initially identified for its function as a repressor of photomorphogenesis. Indeed, csn display a fusca phenotype (characterized by high accumulation of anthocyanins, and small and unviable plants) and de-etiolation under dark conditions. Further characterization of the CSN uncovered its role in the regulation of CRL complexes recycling, by removing the Nedd 8 peptide from the CRLs. Furthermore, characterization of the pleiotropic defects in $\operatorname{cs} n$ mutants in Arabidopsis, Drosophila, and humans showed that the CSN has other functions besides the inhibition of the CRL E3 Ub ligase activity, that were related to its ability to associate with chromatin (Dessau et al., 2008; Singer et al., 2014; Chamovitz, 2009). Accordingly, a recent study suggested that the pleiotropic nature of the CSN is related to its function in regulating DNA methylation. Thus, Arabidopsis $\operatorname{csn} 8$ and $\operatorname{csn} 5 a-1$ mutants showed similar methylation patterns, in overlapping positions, but rather differential to those of wild-type plants (Tuller et al., 2018). Moreover, this pattern correlated with changes in gene expression in these mutants. Although the mechanisms behind 
this regulation are still unknown, the authors suggested that this effect could be due to the impact of the CSN in the stability of many transcription factors, an interference with the activity of DNA methylation-related E3 ligases, or with the capacity of the CSN to directly bind DNA, as demonstrated in Drosophila (Kraft et al., 2008; Deng et al., 2016; Singer et al., 2014). In this context, the convergence of multiple regulatory mechanisms should not be excluded since CSN has an overall effect on diverse CRL4 E3 Ub ligases controlling chromatin accessibility, transcriptional regulation, and RNA stability and export. According to this notion, loss-of-function mutants for CUL4 share similar pleiotropic phenotypes with csn mutants.

\section{mRNA PROCESSING AND EXPORT}

Mature mRNA formation requires the coordination of several processing mechanisms before export to the cytosol for translation occurs. A number of mRNA-binding proteins associates co-transcriptionally with the nascent mRNA to ensure its proper processing, including $5^{\prime}$ end capping, splicing and $3^{\prime}$ end polyadenylation, ending with the nuclear export of mature transcripts (Moore and Proudfoot, 2009).

Alternative polyadenylation has been only recently considered a widespread mechanism in regulating gene expression (Di Giammartino et al., 2011). The physiological relevance of this mechanism in plants can be illustrated by the function of DWD protein FY as a promoter of flowering transition. Arabidopsis FY is the homolog of the yeast and human RNA 3' end processing factors, Pfs2p and WDR33, respectively, which associate to cleavage and polyadenylation complexes (Shi et al., 2009). FY is also able to directly interact with DDB1A/B and forms complexes with CUL4 (Lee et al., 2008). FY acts together with the nuclear RNA binding protein FCA within the flowering autonomous pathway to prevent accumulation of mature mRNAs of the floral repressor FLC. Indeed, both FY and FCA physically interact and both reduce RNA $3^{\prime}$ end processing of FLC transcripts, which downregulates FLC mRNA accumulation, allowing plant flowering (Simpson et al., 2003).

Splicing of precursor mRNAs (pre-mRNAs) through excision of noncoding regions (introns) and joining of adjacent coding regions (exons) is essential for the expression of nearly all eukaryotic protein-coding genes. Splicing is catalyzed by the spliceosome, a large and dynamic ribonucleoprotein (RNP) machinery located in the nucleus. Initially identified in Caenorhabditis elegans, Smul (suppressor of mec-8 and unc521 ) is a spliceosome-associated WD40-repeat protein whose human ortholog interacts with CUL4B-DDB1 complexes in vivo (Higa et al., 2006; Spike et al., 2001). Although highly conserved in plants and metazoans, Smul is absent from budding yeast, suggesting that its function is required for complex splicing patterns (Ulrich et al., 2016). A recent study demonstrated that the Arabidopsis homolog SMU1 also acts as a splicing factor that influences splice site selection and alternative splicing patterns. SMU1 acts prior and during the first catalytic step of splicing and can be a general modulator of splicing patterns in plants (Kanno et al., 2017). It has been suggested that hSmul, as well as Arabidopsis SMU1, could work as DCAF proteins in recognizing spliceosomal targets for ubiquitination (Higa et al., 2006; Chung et al., 2009). In agreement with this notion, key splicing factors undergo ubiquitination in Arabidopsis, suggesting a role for the ubiquitin-proteasome system in regulating spliceosome functions (Sasaki et al., 2015; Kanno et al., 2017). Whether SMU1 is involved in this regulatory mechanism in Arabidopsis remains to be investigated.

The recruitment of RNA export factors occurs in concomitance with transcription. For instance, the yeast THO/TREX (TRanscription-EXport) complex directly interacts with the C-terminal domain (CTD) of RNAPII during transcript elongation. This interaction enables THO/TREX complex recruitment to RNAPII-transcribed genes to facilitate transport of the nascent mRNAs (Meinel et al., 2013). In plants, our knowledge about this mechanism and the factors involved in coordinated mRNA biogenesis and export is much less known. Affinity purification of Arabidopsis TEX1/ THO3-associated proteins showed that the THO core complex resembles that of metazoans, consisting of HPR1, THO2, THO5A/B, THO6, THO7A/B, and TEX1/THO3 (Yelina et al., 2010). TEX1/THO3 and THO6 are DWD proteins and THO6 forms a functional CRL4 E3 Ub ligase that plays also a role in ABA signalling (Lee et al., 2010). Mutants of THO3/TEX1 and THO6 produce reduced amounts of small interfering siRNA, suggesting an additional role of the Arabidopsis THO/TREX in siRNA biosynthesis (Yelina et al., 2010; Jauvion et al., 2010; Sørensen et al., 2017).

The nucleoporin RAE1 (RNA Export Factor 1) is part of the nuclear pore complex (NPC) that acts as a shuttling transport factor at the nuclear envelope to allow mRNAs export (Pritchard et al., 1999; Okamura et al., 2015). Transport between the nucleoplasm and the cytoplasm depends on mRNA recognition by the NPC, which is the largest multiprotein complex in eukaryotic cells. Mass spectrometry analysis of GFP-RAE1 interactors suggested that the Arabidopsis NPC protein composition is very similar to that of vertebrates (Tamura et al., 2010). Arabidopsis RAE1 is itself a DWD domain-containing protein that interacts with DDB1A in Y2H assays (Lee et al., 2008). It would be interesting to determine if RAE1 is a canonical DCAF and to identify its protein targets, which could include other NPC components, chaperones, and, very importantly, passenger proteins or RNAs.

\section{MIRNA BIOGENESIS}

Among the known miRNA biogenesis factors in Arabidopsis, the DWD containing proteins PLEIOTROPIC REGULATORY LOCUS1 (PRL1), PRL2, and MAC3B belong to the MOS4associated complex (MAC) (Lee et al., 2008; Monaghan et al., 2009). MAC is a highly conserved complex among eukaryotes, with its yeast and humans orthologs known as the NineTeen Complex (NTC) and Prp19 complex (Prp19C), respectively. The Arabidopsis MAC, as the yeast and human NTC/Prp19C, associates with the spliceosome. All three complexes are 
predicted to share conserved functions in regulating splicing (Monaghan et al., 2009; Johnson et al., 2011). In Arabidopsis, loss-of-function of MAC, as in mac3a mac3b and prl1 prl2 double mutants, impairs miRNA biogenesis (Jia et al., 2017; Li et al., 2018). Both MAC3B and PRL1 were shown to have E3 Ub ligase activity in vitro. In fact, it has been reported that PRL1 likely acts as a substrate receptor involved in the degradation of the AKIN10 kinase, a key regulator of cell energy homeostasis (Lee et al., 2008; Wiborg et al., 2008; Monaghan et al., 2009).

\section{RIBOSOME BIOGENESIS}

Ribosomes are fundamental macromolecular machines and the basis of the translation machinery, allowing the conversion of information encoded within mRNAs into proteins. The $80 \mathrm{~S}$ ribosome is a ribonucleoprotein complex that comprises two ribosomal subunits, a large $60 \mathrm{~S}$ subunit (containing the $25 \mathrm{~S}$, $5.8 \mathrm{~S}$, and $5 \mathrm{~S}$ rRNAs, and 46 ribosomal proteins) and a small $40 \mathrm{~S}$ subunit (containing the $18 \mathrm{~S}$ rRNA and 33 ribosomal proteins) (Fromont-Racine et al., 2003; Henras et al., 2008). Ribosome biogenesis is an essential process for cell growth and proliferation. Though it is best characterized in yeast by genetic and proteomic studies (Henras et al., 2008; Panse and Johnson, 2010), plants have homologs of yeast and mammalian ribosomal biogenesis factors, despite only a few of them have been studied (Pendle et al., 2005; Horiguchi et al., 2011). Interestingly, a number of DWD proteins have been associated with ribosome biogenesis. For instance, SLOW WALKER1 (SWA1) is a DWD with six WD40 repeats involved in $18 \mathrm{~S}$ rRNA processing (Shi et al., 2005). Characterization of the semisterile Arabidopsis mutant swal showed it is defective in mitotic progression of the female gametophyte, pointing to an essential role for SWA1 during megagametogenesis (Shi et al., 2005). Gametophyte and embryo sac development requires another DWD protein, PERIODIC TRYPTOPHAN PROTEIN 2 (PWP2), a homolog of the yeast Pwp2 protein involved in nucleolar processing of pre-18S ribosomal RNA for $40 \mathrm{~S}$ subunit maturation (Missbach et al., 2013). Despite the presence of putative DWD domains, it is unknown whether SWA1 and PWP2 can associate with CRL4 complexes and form functional E3 ligases.

Arabidopsis YAOZHE (YAO) and EMB2271 are related DWD proteins that display homology to the non-ribosome nucleolar protein Rrp9/hU3-55K from yeast and humans, respectively. Rrp9/hU3-55K are present in the $90 \mathrm{~S}$ preribosome, being essential for $18 \mathrm{~S}$ rRNA maturation and $40 \mathrm{~S}$ subunit biogenesis (Grandi et al., 2002). Mutation of YAO in Arabidopsis reduces competence of male gametophytes as well as, in a reduced number of cases, impairs development of the embryo sacs at the four-nucleate stage, showing aberrant nuclear positioning ( $\mathrm{Li}$ et al., 2010). In addition, yao mutants display misplacement of the cell plate in the zygote and subsequent zygote arrest, leading to early embryo lethality. Thus, YAO is required for gametophyte development and regulation of cell division planes during embryogenesis
(Li et al., 2010). Though a direct interaction with CRL4-DDB1 machinery would be expected, Li and co-workers could not detect physical interaction between $\mathrm{YAO}$ and DDB1A or DDB1B using yeast two-hybrid assays (Li et al., 2010).

The maturation and assembly of the $60 \mathrm{~S}$ ribosomal subunit is also regulated by DWD domain proteins. PEP2 (PESCADILLO ORTHOLOG 2) is the Arabidopsis homolog of human DWD protein WDR12, which is involved in the maturation of $28 \mathrm{~S}$ and $5.8 \mathrm{~S}$ subunits during the formation of the $60 \mathrm{~S}$ ribosome (Zografidis et al., 2014). Arabidopsis PEP2 directly interacts with PESCADILLO (PES), whose homolog in zebrafish is essential for embryonic development. In Arabidopsis PES, BOP (Block of Proliferation 1) and WDR12 also constitute the evolutionarily conserved PeBoW complex involved in cell growth and differentiation that is indispensable for viability of yeast and higher eukaryotes. In response to nucleolar stress or DNA damage, Arabidopsis PeBoW proteins move from the nucleolus to the nucleoplasm. Depletion of PeBoW proteins led to dramatic suppression of cell proliferation, expansion, and differentiation. Concomitantly, PeBoW silencing caused rapid transcriptional modulation of cell-cycle genes, suggesting that, by affecting ribosome biogenesis, this complex plays a critical role in plant cell growth and survival (Ahn et al., 2016). Another DWD protein NOTCHLESS (NLE) is involved in maturation and assembly of the $60 \mathrm{~S}$ ribosomal subunit, and is essential for proper cellular growth and proliferation during plant development (Chantha and Matton, 2007). Silencing of the NLE gene by RNA interference in Arabidopsis led to a semisterile phenotype caused by defects in female gametophyte development, further supporting a role for ribosome biogenesis in female gametophyte development in plants (Chantha et al., 2010).

\section{GENERAL CONCLUSIONS AND FUTURE PERSPECTIVES}

Due to their three dimensional structural features, DWD proteins are prone to be involved in protein-protein interactions. Indeed, numerous DWD proteins are components of different multisubunit complexes including CRL4 E3 Ub ligases. However, a large number of Arabidopsis DWD proteins referred here have not been confirmed as physical interactors of DDB1. It is also unknown whether they contribute to CRL4 E3 Ub ligase activities and which are their precise targets. These might include either unrelated protein substrates (i.e., transcriptional regulators, metabolic enzymes, and structural proteins) or even components of the multi-subunit complexes to which they belong, being necessary to regulate protein complex assembly and/or function. Nevertheless, it cannot be excluded that many of these proteins have conserved the DWD domain during evolution but have lost the capacity to interact with CRL4 complexes, gaining new abilities in the meanwhile.

To date, at least 53 Arabidopsis DWD proteins have been partially characterized. Among those, 32 display a function related to transcriptional output either by regulating abundance of transcription factors, by modulating chromatin 
accessibility or transcript processing. This represents a paradox since, by exerting a tight and selective control of protein degradation, CRL4-associated proteins can regulate transcriptional events and assure correct protein synthesis. Importantly, CRL4 function on nuclear events is very likely not limited to targeted degradation of chromatin-associated factors. Indeed, it is known that CRL4 complexes mediate different kinds of non-proteolytic ubiquitination of protein substrates, including formation of K63-linked polyUb chains and monoUb conjugates (Sugasawa et al., 2005). Such CRL4mediated modifications, instead of triggering degradation of targets, may influence their protein-protein interaction ability, DNA binding capability, or their subcellular localization (Deshaies and Joazeiro, 2009; Dumbliauskas et al., 2011).

The idea that CRL4 ligases are genome caretakers due to their prominent role during DNA replication and repair is not new (Lampert et al., 2017). In Arabidopsis, similar to the case of other organisms, this surveying function can be extended to other mechanisms directly related with DNA transcription. Such a remarkable pleiotropy of functions can only be achieved by the versatility and modular function of CRL4 complexes that assemble into a plethora of functional E3 ligases just by exchanging the substrate recognition modules. It is therefore not surprising that DDB1 was scored as an essential gene in a human genome-wide CRISPR/Cas9 knockout screen (Hart et al., 2015). This situation is analogous to the case of Arabidopsis where total loss of DDB1 function (as shown in null $d d b 1 a d d b 1 b$ double mutants) causes embryolethality (Bernhardt et al., 2010).

Despite our increasing knowledge on the chromatinassociated functions of Arabidopsis DCAFs, a large number of them are still orphan substrate receptors, whose function is completely unknown. Further efforts should be dedicated to fill

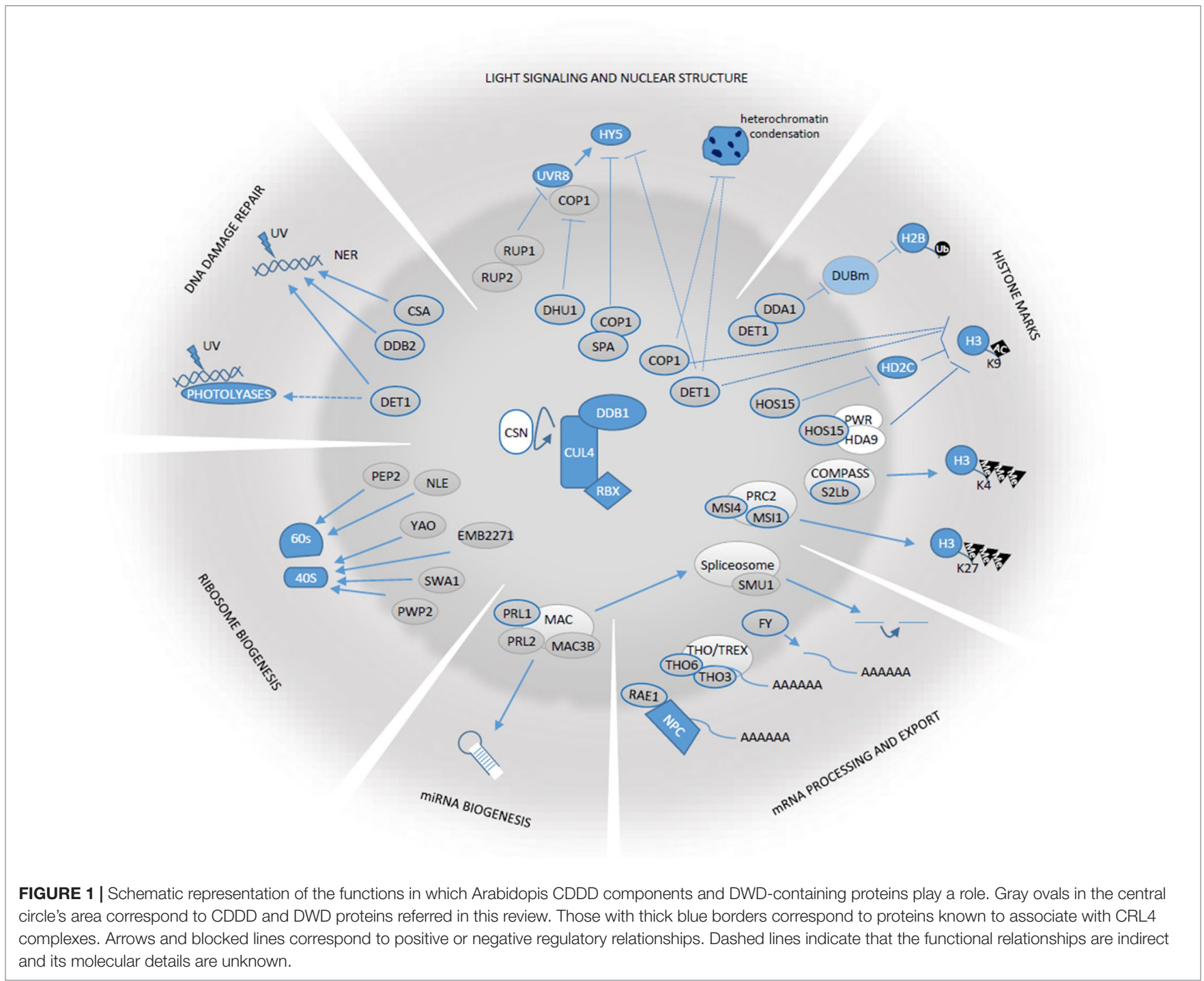


this gap, providing a better understanding on the roles of CRL4associated DCAFs in shaping nuclear architecture, epigenetic landscape, and gene expression throughout the plant life cycle.

\section{AUTHOR CONTRIBUTIONS}

SF gathered information, designed and wrote the manuscript, and drew Figure 1.

VR revised and edited the manuscript.

\section{FUNDING}

SF has a Ramon y Cajal grant RYC-2014-16308 funded by the Ministerio de Economia y Competitividad. Work in VR

\section{REFERENCES}

Ach, R. A., Taranto, P., and Gruissem, W. (1997). A conserved family of WD-40 proteins binds to the retinoblastoma protein in both plants and animals. Plant Cell 9 (9), 1595-1606. doi: 10.1105/tpc.9.9.1595

Ahn, C. S., Cho, H. K., Lee, D.-H., Sim, H.-J., Kim, S.-G., and Pai, H.-S. (2016). Functional characterization of the ribosome biogenesis factors PES, BOP1, and WDR12 (PeBoW), and mechanisms of defective cell growth and proliferation caused by PeBoW deficiency in Arabidopsis. J. Exper. Bot. 67 (17), 5217-5232. doi: 10.1093/jxb/erw288

Aihara, Y., Fujimura-Kamada, K., Yamasaki, T., and Minagawa, J. (2019). Algal photoprotection is regulated by the E3 ligase CUL4-DDB1 DET1. Nature Plants 5 (1), 34. doi: 10.1038/s41477-018-0332-5

Al Khateeb, W. M., and Schroeder, D. F. (2009). Overexpression of Arabidopsis damaged DNA binding protein 1A (DDB1A) enhances UV tolerance. Plant Mol. Biol. 70 (4), 371-383. doi: 10.1007/s11103-009-9479-9

Ang, L. H., Chattopadhyay, S., Wei, N., Oyama, T., Okada, K., Batschauer, A, et al. (1998) Molecular interaction between COP1 and HY5 defines a regulatory switch for light control of Arabidopsis development. Mol. Cell 1 (2), 213-222.

Ang, L. H., and Deng, X. W. (1994). Regulatory hierarchy of photomorphogenic loci: allele-specific and light-dependent interaction between the HY5 and COP1 loci. Plant Cell 6 (5), 613. doi: 10.1105/tpc.6.5.613

Angers, S., Li, T., Yi, X., MacCoss, M. J., Moon, R. T., and Zheng, N. (2006). Molecular architecture and assembly of the DDB1-CUL4A ubiquitin ligase machinery. Nature 443 (7111), 590. doi: 10.1038/nature05175

Benvenuto, G., Formiggini, F., Laflamme, P., Malakhov, M., and Bowler, C. (2002). The photomorphogenesis regulator DET1 binds the amino-terminal tail of histone H2B in a nucleosome context. Curr. Biol. 12 (17), 1529-1534. doi: 10.1016/S0960-9822(02)01105-3

Beris, D., Kapolas, G., Livanos, P., Roussis, A., Milioni, D., and Haralampidis, K. (2016). RNAi-mediated silencing of the Arabidopsis thaliana ULCS1 gene, encoding a WDR protein, results in cell wall modification impairment and plant infertility. Plant Sci. 245, 71-83. doi: 10.1016/j.plantsci.2016.01.008

Bernhardt, A., Lechner, E., Hano, P., Schade, V., Dieterle, M., Anders, M., et al. (2006). CUL4 associates with DDB1 and DET1 and its downregulation affects diverse aspects of development in Arabidopsis thaliana. Plant J. 47 (4), 591603. doi: 10.1111/j.1365-313X.2006.02810.x

Bernhardt, A., Mooney, S., and Hellmann, H. (2010). Arabidopsis DDB1a and DDB1b are critical for embryo development. Plant J. 232 (3), 555-566. doi: 10.1007/s00425-010-1195-9

Bian, S., Li, X., Mainali, H., Chen, L., and Dhaubhadel, S. (2017). Genomewide analysis of DWD proteins in soybean (Glycine max): significance of Gm08DWD and GmMYB176 interaction in isoflavonoid biosynthesis. PLoS One 12 (6), e0178947. doi: 10.1371/journal.pone.0178947

Biedermann, S., and Hellmann, H. (2010). The DDB1a interacting proteins ATCSA-1 and DDB2 are critical factors for UV-B tolerance and laboratory is funded by the Project BIO2016-80551-R by Agencia Estatal de Investigación/Fondo Europeo de Desarollo Regional/ European Union.

\section{ACKNOWLEDGMENTS}

We apologize to those authors whose relevant work could not be cited due to space limitation.

\section{SUPPLEMENTARY MATERIAL}

The Supplementary Material for this article can be found online at: https://www.frontiersin.org/articles/10.3389/fpls.2019.01095/ full\#supplementary-material

genomic integrity in Arabidopsis thaliana. Plant J. 62 (3), 404-415. doi: 10.1111/j.1365-313X.2010.04157.x

Biedermann, S., and Hellmann, H. (2011). WD40 and CUL4-based E3 ligases: lubricating all aspects of life. Trends Plant Sci. 16 (1), 38-46. doi: 10.1016/j. tplants.2010.09.007

Binkert, M., Crocco, C. D., Ekundayo, B., Lau, K., Raffelberg, S., Tilbrook, K., et al. (2016). Revisiting chromatin binding of the Arabidopsis UV-B photoreceptor UVR8. BMC Plant Biol. 16 (1), 42. doi: 10.1186/s12870-016-0732-5

Bourbousse, C., Ahmed, I., Roudier, F., Zabulon, G., Blondet, E., Balzergue, S., et al. (2012). Histone H2B monoubiquitination facilitates the rapid modulation of gene expression during Arabidopsis photomorphogenesis. PLoS Genet. 8 (7), e1002825. doi: 10.1371/journal.pgen.1002825

Bourbousse, C., Mestiri, I., Zabulon, G., Bourge, M., Formiggini, F., Koini, M. A., et al. (2015). Light signaling controls nuclear architecture reorganization during seedling establishment. Proc. Natl. Acad. Sci. 112 (21), E2836. doi: 10.1073/pnas.1503512112

Castells, E., Molinier, J., Benvenuto, G., Bourbousse, C., Zabulon, G., Zalc, A., et al. (2011). The conserved factor DE-ETIOLATED 1 cooperates with CUL4DDB1DDB2 to maintain genome integrity upon UV stress. EMBO J. 30 (6), 1162-1172. doi: 10.1038/emboj.2011.20

Castells, E., Molinier, J., Drevensek, S., Genschik, P., Barneche, F., and Bowler, C. (2010). det1-1-induced UV-C hyposensitivity through UVR3 and PHR1 photolyase gene over-expression. Plant J. 63 (3), 392-404. doi: 10.1111/j. 1365-313X.2010.04249.x

Chantha, S.-C., Gray-Mitsumune, M., Houde, J., and Matton, D. P. (2010). The MIDASIN and NOTCHLESS genes are essential for female gametophyte development in Arabidopsis thaliana. Physiol. Mol. Biol. Plants 16 (1), 3-18. doi: 10.1007/s12298-010-0005-y

Chantha, S.-C., and Matton, D. P. (2007). Underexpression of the plant NOTCHLESS gene, encoding a WD-repeat protein, causes pleitropic phenotype during plant development. Planta 225 (5), 1107-1120. doi: 10.1007/s00425-006-0420-z

Chamovitz, D. A. (2009). Revisiting the COP9 signalosome as a transcriptional regulator. EMBO Reports 10 (4), 352-358. doi: 10.1038/embor.2009.33

Chen, H., Shen, Y., Tang, X., Yu, L., Wang, J., Guo, L., et al. (2006). Arabidopsis CULLIN4 forms an E3 ubiquitin ligase with RBX1 and the CDD complex in mediating light control of development. Plant Cell 18 (8), 1991-2004. doi: 10.1105/tpc.106.043224

Chen, H., Huang, X., Gusmaroli, G., Terzaghi, W., Lau, O. S., Yanagawa, Y., et al. (2010). Arabidopsis CULLIN4-damaged DNA binding protein 1 interacts with constitutively photomorphogenic1-suppressor of phya complexes to regulate photomorphogenesis and flowering time. Plant Cell 22 (1), 108-123. doi: 10.1105/tpc.109.065490

Cheng, L., Yang, Q., Li, C., Dai, L., Yang, Y., Wang, Q., et al. (2017). DDA 1, a novel oncogene, promotes lung cancer progression through regulation of cell cycle. J. Cell. Mol. Med. 21 (8), 1532-1544. doi: 10.1111/jcmm.13084

Chung, T., Wang, D., Kim, C.-S., Yadegari, R., and Larkins, B. A. (2009). Plant SMU-1 and SMU-2 homologues regulate pre-mRNA splicing and multiple 
aspects of development. Plant Physiol. 151 (3), 1498-1512. doi: 10.1104/ pp.109.141705

Cloix, C., and Jenkins, G. I. (2008). Interaction of the Arabidopsis UV-B-specific signaling component UVR8 with chromatin. Mol. Plant 1 (1), 118-128. doi: $10.1093 / \mathrm{mp} / \mathrm{ssm} 012$

Deng, S., Jang, I.-C., Su, L., Xu, J., and Chua, N.-H. (2016). JMJ24 targets CHROMOMETHYLASE3 for proteasomal degradation in Arabidopsis. Genes Dev. 30 (3), 251-256. doi: 10.1101/gad.274647.115

Deshaies, R. J., and Joazeiro, C. A. (2009). RING domain E3 ubiquitin ligases. Annu. Rev. Biochem. 78, 399-434. doi: 10.1146/annurev.biochem.78.101807.093809

Dessau, M., Halimi, Y., Erez, T., Chomsky-Hecht, O., Chamovitz, D. A., and Hirsch, J. A. (2008). The Arabidopsis COP9 signalosome subunit 7 is a model PCI domain protein with subdomains involved in COP9 signalosome assembly. Plant Cell 20 (10), 2815-2834. doi: 10.1105/tpc.107.053801

Di Giammartino, D. C., Nishida, K., and Manley, J. L. (2011). Mechanisms and consequences of alternative polyadenylation. Mol. Cell 43 (6), 853-866. doi: 10.1016/j.molcel.2011.08.017

Dong, J., Tang, D., Gao, Z., Yu, R., Li, K., He, H., et al. (2014). Arabidopsis DE-ETIOLATED1 represses photomorphogenesis by positively regulating phytochrome-interacting factors in the dark. Plant Cell 26 (9), 3630-3645. doi: $10.1105 /$ tpc. 114.130666

Dumbliauskas, E., Lechner, E., Jaciubek, M., Berr, A., Pazhouhandeh, M., Alioua, M., et al. (2011). The Arabidopsis CUL4-DDB1 complex interacts with MSI1 and is required to maintain MEDEAparental imprinting. EMBO J. 30 (4), 731-743. doi: 10.1038/emboj.2010.359

Favory, J. J., Stec, A., Gruber, H., Rizzini, L., Oravecz, A., Funk, M., et al. (2009). Interaction of COP1 and UVR8 regulates UV-B-induced photomorphogenesis and stress acclimation in Arabidopsis. EMBO J. 28 (5), 591-601. doi: 10.1038/ emboj.2009.4

Fiorucci, A.-S., Bourbousse, C., Concia, L., Rougée, M., Deton-Cabanillas, A.-F., Zabulon, G., et al. (2019). Arabidopsis S2Lb links AtCOMPASS-like and SDG2 activity in $\mathrm{H} 3 \mathrm{~K} 4 \mathrm{me} 3$ independently from histone $\mathrm{H} 2 \mathrm{~B}$ monoubiquitination. Genome Biol. 20 (1), 100. doi: 10.1186/s13059-019-1705-4

Fischer, E. S., Scrima, A., Böhm, K., Matsumoto, S., Lingaraju, G. M., Faty, M., et al. (2011). The molecular basis of CRL4DDB2/CSA ubiquitin ligase architecture, targeting, and activation. Cell 147 (5), 1024-1039. doi: 10.1016/j.cell.2011. 10.035

Fromont-Racine, M., Senger, B., Saveanu, C., and Fasiolo, F. (2003). Ribosome assembly in eukaryotes. Gene 313, 17-42. doi: 10.1016/S0378-1119(03)00629-2

Gao, S., Geng, C., Song, T., Lin, X., Liu, J., Cai, Z., et al. (2017). Activation of c-Abl kinase potentiates the anti-myeloma drug lenalidomide by promoting DDA1 protein recruitment to the CRL4 ubiquitin ligase. J. Biol. Chem. 292 (9), 36833691. doi: 10.1074/jbc.M116.761551

Grandi, P., Rybin, V., Baßler, J., Petfalski, E., Strauß, D., Marzioch, M., et al. (2002). 90 S pre-ribosomes include the $35 \mathrm{~S}$ pre-rRNA, the U3 snoRNP, and $40 \mathrm{~S}$ subunit processing factors but predominantly lack 60S synthesis factors. Mol. Cell 10 (1), 105-115. doi: 10.1016/S1097-2765(02)00579-8

Gruber, H., Heijde, M., Heller, W., Albert, A., Seidlitz, H. K., and Ulm, R. (2010). Negative feedback regulation of UV-B-induced photomorphogenesis and stress acclimation in Arabidopsis. Proc. Natl. Acad. Sci. 107 (46), 20132-20137. doi: 10.1073/pnas.0914532107

Guo, L., Zhou, J., Elling, A. A., Charron, J.-B. F., and Deng, X. W. (2008). Histone modifications and expression of light-regulated genes in Arabidopsis are cooperatively influenced by changing light conditions. Plant Physiol. 147 (4), 2070-2083. doi: 10.1104/pp.108.122929

Hart, T., Chandrashekhar, M., Aregger, M., Steinhart, Z., Brown, K. R., MacLeod, G., et al. (2015). High-resolution CRISPR screens reveal fitness genes and genotype-specific cancer liabilities. Cell 163 (6), 1515-1526. doi: 10.1016/j.cell. 2015.11.015

He, Y. J., McCall, C. M., Hu, J., Zeng, Y., and Xiong, Y. (2006). DDB1 functions as a linker to recruit receptor WD40 proteins to CUL4-ROC1 ubiquitin ligases. Genes Dev. 20 (21), 2949-2954. doi: 10.1101/gad.1483206

Heijde, M., and Ulm, R. (2013). Reversion of the Arabidopsis UV-B photoreceptor UVR8 to the homodimeric ground state. Proc. Natl. Acad. Sci. 110 (3), 11131118. doi: $10.1073 /$ pnas. 1214237110

Henras, A., Soudet, J., Gerus, M., Lebaron, S., Caizergues-Ferrer, M., Mougin, A., et al. (2008). The post-transcriptional steps of eukaryotic ribosome biogenesis. Cell. Mol. Life Sci. 65 (15), 2334-2359. doi: 10.1007/s00018-008-8027-0
Higa, L. A., Wu, M., Ye, T., Kobayashi, R., Sun, H., and Zhang, H. (2006). CUL4DDB1 ubiquitin ligase interacts with multiple WD40-repeat proteins and regulates histone methylation. Nat. Cell Biol. 8 (11), 1277-1283. doi: 10.1038/ ncb1490

Higa, L. A., and Zhang, H. (2007). Stealing the spotlight: CUL4-DDB1 ubiquitin ligase docks WD40-repeat proteins to destroy. Cell Div. 2, 5-5. doi: 10.1186/ 1747-1028-2-5

Hoeijmakers, J. H. (2009). DNA damage, aging, and cancer. N. Engl. J. Med. 361 (15), 1475-1485. doi: 10.1056/NEJMra0804615

Hoecker, U., Tepperman, J. M., and Quail, P. H. (1999). SPA1, a WD-repeat protein specific to phytochrome A signal transduction. Science 284 (5413), 496-499. doi: $10.1126 /$ science.284.5413.496

Holm, M., Ma, L.-G., Qu, L.-J., and Deng, X.-W. (2002). Two interacting bZIP proteins are direct targets of COP1-mediated control of light-dependent gene expression in Arabidopsis. Genes Dev. 16 (10), 1247-1259. doi: 10.1101/ gad. 969702

Horiguchi, G., Mollá-Morales, A., Pérez-Pérez, J. M., Kojima, K., Robles, P., Ponce, M. R., et al. (2011). Differential contributions of ribosomal protein genes to Arabidopsis thaliana leaf development. Plant J. 65 (5), 724-736. doi: 10.1111/j.1365-313X.2010.04457.x

Hu, J., McCall, C. M., Ohta, T., and Xiong, Y. (2004). Targeted ubiquitination of CDT1 by the DDB1-CUL4A-ROC1 ligase in response to DNA damage. Nat. Cell Biol. 6 (10), 1003-1009. doi: 10.1038/ncb1172

Irigoyen, M. L., Iniesto, E., Rodriguez, L., Puga, M. I., Yanagawa, Y., Pick, E., et al. (2014). Targeted degradation of abscisic acid receptors is mediated by the ubiquitin ligase substrate adaptor DDA1 in Arabidopsis. Plant Cell 26 (2), 712-728. doi: 10.1105/tpc.113.122234

Jackson, S., and Xiong, Y. (2009). CRL4s: the CUL4-RING E3 ubiquitin ligases. Trends Biochem. Sci. 34 (11), 562-570. doi: 10.1016/j.tibs.2009.07.002

Jauvion, V., Elmayan, T., and Vaucheret, H. (2010). The conserved RNA trafficking proteins HPR1 and TEX1 are involved in the production of endogenous and exogenous small interfering RNA in Arabidopsis. Plant Cell 22 (8), 2697-2709. doi: $10.1105 /$ tpc. 110.076638

Jang, I.-C., Yang, J.-Y., Seo, H. S., and Chua, N.-H. (2005). HFR1 is targeted by COP1 E3 ligase for post-translational proteolysis during phytochrome A signaling. Genes Dev. 19 (5), 593-602. doi: 10.1101/gad.1247205

Jia, T., Zhang, B., You, C., Zhang, Y., Zeng, L., Li, S., et al. (2017). The Arabidopsis MOS4-associated complex promotes microRNA biogenesis and precursor messenger RNA splicing. Plant Cell 29 (10), 2626. doi: 10.1105/tpc.17.00370

Jiao, Y., Lau, O. S., and Deng, X. W. (2007). Light-regulated transcriptional networks in higher plants. Nat. Rev. Genet. 8 (3), 217-230. doi: 10.1038/nrg2049

Johnson, K. C. M., Dong, O. X., and Li, X. (2011). The evolutionarily conserved MOS4-associated complex. Cent. Eur. J. Biol. 6 (5), 776. doi: 10.2478/s11535011-0043-7

Kanno, T., Lin, W.-D., Fu, J. L., Matzke, A. J. M., and Matzke, M. (2017). A genetic screen implicates a CWC16/Yju2/CCDC130 protein and SMU1 in alternative splicing in Arabidopsis thaliana. RNA 23 (7), 1068-1079. doi: 10.1261/rna.060517.116

Kapolas, G., Beris, D., Katsareli, E., Livanos, P., Zografidis, A., Roussis, A., et al. (2016). APRF1 promotes flowering under long days in Arabidopsis thaliana. Plant Sci. 253, 141-153. doi: 10.1016/j.plantsci.2016.09.015

Kendrick, R. E., and Kronenberg, G. H. (2012). Photomorphogenesis in plants. 2nd Edn. (Dordrecht: Springer Science \& Business Media).

Kim, J., Guermah, M., McGinty, R. K., Lee, J.-S., Tang, Z., Milne, T. A., et al. (2009). RAD6-Mediated transcription-coupled $\mathrm{H} 2 \mathrm{~B}$ ubiquitylation directly stimulates H3K4 methylation in human cells. Cell 137 (3), 459-471. doi: 10.1016/j. cell.2009.02.027

Kim, S.-H., Kim, H., Chung, S., and Lee, J.-H. (2017). DHU1 negatively regulates UV-B signaling via its direct interaction with COP1 and RUP1. Biochem. Biophys. Res. Commun. 491 (2), 285-290. doi: 10.1016/j.bbrc.2017.07.110

Kim, S.-H., Kim, H., Seo, K.-I., Kim, S.-H., Chung, S., Huang, X., et al. (2014). DWD HYPERSENSITIVE TO UV-B 1 is negatively involved in UV-B mediated cellular responses in Arabidopsis. Plant Mol. Biol. 86 (6), 571-583. doi: 10.1007/s11103-014-0247-0

Kimura, S., Tahira, Y., Ishibashi, T., Mori, Y., Mori, T., Hashimoto, J., et al. (2004). DNA repair in higher plants; photoreactivation is the major DNA repair pathway in non-proliferating cells while excision repair (nucleotide excision repair and base excision repair) is active in proliferating cells. Nucleic Acids Res. 32 (9), 2760-2767. doi: 10.1093/nar/gkh591 
Kliebenstein, D. J., Lim, J. E., Landry, L. G., and Last, R. L. (2002). Arabidopsis UVR8 regulates ultraviolet-B signal transduction and tolerance and contains sequence similarity to human regulator of chromatin condensation 1 . Plant Physiol. 130 (1), 234-243. doi: 10.1104/pp.005041

Koga, A., Ishibashi, T., Kimura, S., Uchiyama, Y., and Sakaguchi, K. (2006). Characterization of T-DNA insertion mutants and RNAi silenced plants of Arabidopsis thaliana UV-damaged DNA binding protein 2 (AtUV-DDB2). Plant Mol. Biol. 61 (1-2), 227-240. doi: 10.1007/s11103-006-6408-Z

Kraft, E., Bostick, M., Jacobsen, S. E., and Callis, J. (2008). ORTH/VIM proteins that regulate DNA methylation are functional ubiquitin E3 ligases. Plant J. 56 (5), 704-715. doi: 10.1111/j.1365-313X.2008.03631.x

Lampert, F., Brodersen, M. M. L., and Peter, M. (2017). Guard the guardian: a CRL4 ligase stands watch over histone production. Nucleus 8 (2), 134-143. doi: 10.1080/19491034.2016.1276143

Lau, O. S., and Deng, X. W. (2009). Effect of Arabidopsis COP10 ubiquitin E2 enhancement activity across E2 families and functional conservation among its canonical homologues. Biochem. J. 418 (3), 683-690. doi: 10.1042/BJ20081943

Lau, O. S., and Deng, X. W. (2012). The photomorphogenic repressors COP1 and DET1: 20 years later. Trends Plant Sci. 17 (10), 584-593. doi: 10.1016/j. tplants.2012.05.004

Lau, O. S., Huang, X., Charron, J.-B., Lee, J.-H., Li, G., and Deng, X. W. (2011). Interaction of Arabidopsis DET1 with CCA1 and LHY in mediating transcriptional repression in the plant circadian clock. Mol. Cell 43 (5), $703-$ 712. doi: 10.1016/j.molcel.2011.07.013

Laubinger, S., and Hoecker, U. (2003). The SPA1-like proteins SPA3 and SPA4 repress photomorphogenesis in the light. Plant J. 35 (3), 373-385. doi: 10.1046/j.1365-313X.2003.01813.x

Laubinger, S., Marchal, V., Gentilhomme, J., Wenkel, S., Adrian, J., Jang, S., et al. (2006). ArabidopsisSPA proteins regulate photoperiodic flowering and interact with the floral inducer CONSTANS to regulate its stability. Development 133 (16), 3213-3222. doi: 10.1242/dev.02481

Lee, J.-H., Terzaghi, W., Gusmaroli, G., Charron, J.-B. F., Yoon, H.-J., Chen, H., et al. (2008). Characterization of Arabidopsis and rice DWD proteins and their roles as substrate receptors for CUL4-RING E3 ubiquitin ligases. Plant Cell 20 (1), 152. doi: 10.1105/tpc.107.055418

Lee, J.-H., Yoon, H.-J., Terzaghi, W., Martinez, C., Dai, M., Li, J., et al. (2010). DWA1 and DWA2, two Arabidopsis DWD protein components of CUL4based E3 ligases, act together as negative regulators in ABA signal transduction. Plant Cell 22 (6), 1716-1732. doi: 10.1105/tpc.109.073783

Lee, J., and Zhou, P. (2007). DCAFs, the missing link of the CUL4-DDB1 ubiquitin ligase. Mol. Cell 26 (6), 775-780. doi: 10.1016/j.molcel.2007.06.001

Li, H.-J., Liu, N.-Y., Shi, D.-Q., Liu, J., and Yang, W.-C. (2010). YAO is a nucleolar WD40-repeat protein critical for embryogenesis and gametogenesis in Arabidopsis. BMC Plant Biol. 10 (1), 169. doi: 10.1186/1471-2229-10-169

Li, S., Liu, K., Zhou, B., Li, M., Zhang, S., Zeng, L., et al. (2018). MAC3A and MAC3B, two core subunits of the MOS4-associated complex, positively influence miRNA biogenesis. Plant Cell 30 (2), 481. doi: 10.1105/ tpc. 17.00953

Li, T., Chen, X., Garbutt, K. C., Zhou, P., and Zheng, N. (2006). Structure of DDB1 in complex with a paramyxovirus $\mathrm{V}$ protein: viral hijack of a propeller cluster in ubiquitin ligase. Cell 124 (1), 105-117. doi: 10.1016/j.cell.2005.10.033

Liu, L.-J., Zhang, Y.-C., Li, Q.-H., Sang, Y., Mao, J., Lian, H.-L., et al. (2008). COP1-mediated ubiquitination of CONSTANS is implicated in cryptochrome regulation of flowering in Arabidopsis. Plant Cell 20 (2), 292-306. doi: 10.1105/ tpc.107.057281

Luger, K., Mäder, A. W., Richmond, R. K., Sargent, D. F., and Richmond, T. J. (1997). Crystal structure of the nucleosome core particle at $2.8 \AA$ resolution. Nature 389 (6648), 251-260. doi: 10.1038/38444

Mayer, K. S., Chen, X., Sanders, D., Chen, J., Jiang, J., Nguyen, P., et al. (2019). HDA9-PWR-HOS15 is a core histone deacetylase complex regulating transcription and development. Plant Physiol. 180 (1), 342-355. doi: 10.1104/ pp. 18.01156

McCall, C. M., Hu, J., and Xiong, Y. (2005). Recruiting substrates to cullin 4-dependent ubiquitin ligases by DDB1. Cell Cycle 4 (1), 27-29. doi: 10.4161/ cc.4.1.1396

Meinel, D. M., Burkert-Kautzsch, C., Kieser, A., O’Duibhir, E., Siebert, M., Mayer, A., et al. (2013). Recruitment of TREX to the transcription machinery by its direct binding to the phospho-CTD of RNA polymerase II. PLoS Genet. 9 (11), e1003914-e1003914. doi: 10.1371/journal.pgen.1003914

Migliori, V., Mapelli, M., and Guccione, E. (2012). On WD40 proteins: propelling our knowledge of transcriptional control? Epigenetics 7 (8), 815-822. doi: 10.4161/epi.21140

Missbach, S., Weis, B. L., Martin, R., Simm, S., Bohnsack, M. T., and Schleiff, E. (2013). 40S ribosome biogenesis co-factors are essential for gametophyte and embryo development. PLoS One 8 (1), e54084. doi: 10.1371/journal. pone. 0054084

Mitchell, D. L., Adair, G. M., and Nairn, R. S. (1989). Inhibition of transient gene expression in chinese, hamster ovary cells by triplet-sensitized uv-b irradiation of transfected DNA. Photochem. Photobiol. 50 (5), 639-646. doi: 10.1111/ j.1751-1097.1989.tb04320.x

Molinier, J. (2017). Genome and epigenome surveillance processes underlying UV exposure in plants. Genes (Basel) 8 (11), 316. doi: 10.3390/genes8110316

Molinier, J., Lechner, E., Dumbliauskas, E., and Genschik, P. (2008). Regulation and role of Arabidopsis CUL4-DDB1A-DDB2 in maintaining genome integrity upon UV stress. PLoS Genet. 4 (6), e1000093. doi: 10.1371/journal. pgen.1000093

Monaghan, J., Xu, F., Gao, M., Zhao, Q., Palma, K., Long, C., et al. (2009). Two Prp19-like U-box proteins in the MOS4-associated complex play redundant roles in plant innate immunity. PLoS Pathog. 5 (7), e1000526. doi: 10.1371/ journal.ppat.1000526

Moore, M. J., and Proudfoot, N. J. (2009). Pre-mRNA processing reaches back to transcription and ahead to translation. Cell 136 (4), 688-700. doi: 10.1016/j. cell.2009.02.001

Nakagawa, T., and Xiong, Y. (2011). X-linked mental retardation gene CUL4B targets ubiquitylation of $\mathrm{H} 3 \mathrm{~K} 4$ methyltransferase component WDR5 and regulates neuronal gene expression. Mol. Cell 43 (3), 381-391. doi: 10.1016/j. molcel.2011.05.033

Nassrallah, A., Rougee, M., Bourbousse, C., Drevensek, S., Fonseca, S., Iniesto, E., et al. (2018). DET1-mediated degradation of a SAGA-like deubiquitination module controls H2Bub homeostasis. Elife 7, e37892. doi: 10.7554/eLife.37892

Nixdorf, M., and Hoecker, U. (2010). SPA1 and DET1 act together to control photomorphogenesis throughout plant development. Planta 231 (4), 825-833. doi: 10.1007/s00425-009-1088-y

Okamura, M., Inose, H., and Masuda, S. (2015). RNA Export through the NPC in Eukaryotes. Genes (Basel) 6 (1), 124-149. doi: 10.3390/genes6010124

Olma, M. H., Roy, M., Le Bihan, T., Sumara, I., Maerki, S., Larsen, B., et al. (2009). An interaction network of the mammalian COP9 signalosome identifies Dda1 as a core subunit of multiple Cul4-based E3 ligases. J. Cell Sci. 122 (7), 10351044. doi: 10.1242/jcs.043539

Oravecz, A., Baumann, A., Máté, Z., Brzezinska, A., Molinier, J., Oakeley, E. J., et al. (2006). Constitutively photomorphogenicl is required for the UV-B response in Arabidopsis. Plant Cell 18 (8), 1975-1990. doi: 10.1105/tpc.105.040097

Osterlund, M. T., Hardtke, C. S., Wei, N., and Deng, X. W. (2000). Targeted destabilization of HY5 during light-regulated development of Arabidopsis. Nature 405 (6785), 462-466. doi: 10.1038/35013076

Panse, V. G., and Johnson, A. W. (2010). Maturation of eukaryotic ribosomes: acquisition of functionality. Trends Biochem. Sci. 35 (5), 260-266. doi: 10.1016/ j.tibs.2010.01.001

Park, H. J., Baek, D., Cha, J.-Y., Liao, X., Kang, S.-H., McClung, C. R., et al. (2019). HOS15 interacts with the histone deacetylase HDA9 and the Evening Complex to epigenetically regulate the floral activator GIGANTEA. Plant Cell 31 (1), 37-51. doi: 10.1105/tpc.18.00721

Park, J., Lim, C. J., Khan, I. U., Jan, M., Khan, H. A., Park, H. J., et al. (2018a). Identification and Molecular Characterization of HOS15-interacting Proteins in Arabidopsis thaliana. J. Plant Biol. 61 (5), 336-345. doi: 10.1007/ s12374-018-0313-2

Park, J., Lim, C. J., Shen, M., Park, H. J., Cha, J.-Y., Iniesto, E., et al. (2018b). Epigenetic switch from repressive to permissive chromatin in response to cold stress. Proc. Natl. Acad. Sci. 115 (23), E5400-E5409. doi: 10.1073/ pnas. 1721241115

Pazhouhandeh, M., Molinier, J., Berr, A., and Genschik, P. (2011). MSI4/FVE interacts with CUL4-DDB1 and a PRC2-like complex to control epigenetic regulation of flowering time in Arabidopsis. Proc. Natl. Acad. Sci. 108 (8), 3430-3435. doi: 10.1073/pnas.1018242108 
Pendle, A. F., Clark, G. P., Boon, R., Lewandowska, D., Lam, Y. W., Andersen, J., et al. (2005). Proteomic analysis of the Arabidopsis nucleolus suggests novel nucleolar functions. Mol. Biol Cell 16 (1), 260-269. doi: 10.1091/mbc. e04-09-0791

Pepper, A., Delaney, T., Washburnt, T., Poole, D., and Chory, J. (1994). DET1, a negative regulator of light-mediated development and gene expression in arabidopsis, encodes a novel nuclear-localized protein. Cell 78 (1), 109-116. doi: 10.1016/0092-8674(94)90577-0

Pick, E., Lau, O.-S., Tsuge, T., Menon, S., Tong, Y., Dohmae, N., et al. (2007). Mammalian DET1 regulates Cul4A activity and forms stable complexes with E2 ubiquitin-conjugating enzymes. Mol. Cell. Biol. 27 (13), 4708. doi: 10.1128/ MCB.02432-06

Pritchard, C. E., Fornerod, M., Kasper, L. H., and van Deursen, J. M. (1999). RAE1 is a shuttling mRNA export factor that binds to a GLEBS-like NUP98 motif at the nuclear pore complex through multiple domains. J. Cell Biol. 145 (2), 237-254. doi: 10.1083/jcb.145.2.237

Ries, G., Heller, W., Puchta, H., Sandermann, H., Seidlitz, H. K., and Hohn, B. (2000). Elevated UV-B radiation reduces genome stability in plants. Nature 406 (6791), 98. doi: 10.1038/35017595

Rizzini, L., Favory, J.-J., Cloix, C., Faggionato, D., O’Hara, A., Kaiserli, E., et al. (2011). Perception of UV-B by the Arabidopsis UVR8 protein. Science 332 (6025), 103-106. doi: 10.1126/science.1200660

Rozema, J., Bjorn, L. O., Bornman, J. F., Gaberscik, A., Hader, D. P., Trost, T., et al. (2002). The role of UV-B radiation in aquatic and terrestrial ecosystems-an experimental and functional analysis of the evolution of UV-absorbing compounds. J. Photochem. Photobiol. B, Biol. 66 (1), 2-12. doi: 10.1016/ S1011-1344(01)00269-X

Saijo, Y., Sullivan, J. A., Wang, H., Yang, J., Shen, Y., Rubio, V., et al. (2003). The COP1-SPA1 interaction defines a critical step in phytochrome A-mediated regulation of HY5 activity. Genes Dev. 17 (21), 2642-2647. doi: 10.1101/ gad. 1122903

Sasaki, T., Kanno, T., Liang, S.-C., Chen, P.-Y., Liao, W.-W., Lin, W.-D., et al. (2015). An Rtf2 domain-containing protein influences pre-mRNA splicing and is essential for embryonic development in Arabidopsis thaliana. Genetics 200 (2), 523. doi: $10.1534 /$ genetics. 115.176438

Schroeder, D. F., Gahrtz, M., Maxwell, B. B., Cook, R. K., Kan, J. M., Alonso, J. M., et al. (2002). De-etiolated 1 and damaged DNA binding protein 1 interact to regulate Arabidopsis photomorphogenesis. Curr. Biol. 12 (17), 1462-1472. doi: 10.1016/S0960-9822(02)01106-5

Schuettengruber, B., Bourbon, H.-M., Di Croce, L., and Cavalli, G. (2017). Genome regulation by polycomb and trithorax: 70 years and counting. Cell 171 (1), 34-57. doi: 10.1016/j.cell.2017.08.002

Scrima, A., Fischer, E. S., Lingaraju, G. M., Böhm, K., Cavadini, S., and Thomä, N. H. (2011). Detecting UV-lesions in the genome: the modular CRL4 ubiquitin ligase does it best! FEBS Lett. 585 (18), 2818-2825. doi: 10.1016/j. febslet.2011.04.064

Shabek, N., Ruble, J., Waston, C. J., Garbutt, K. C., Hinds, T. R., Li, T., et al. (2018). Structural insights into DDAl function as a core component of the CRL4-DDB1 ubiquitin ligase. Cell Disc. 4 (1), 67. doi: 10.1038/ s41421-018-0064-8

Shi, D.-Q., Liu, J., Xiang, Y.-H., Ye, D., Sundaresan, V., and Yang, W.-C. (2005). SLOW WALKER1, essential for gametogenesis in Arabidopsis, encodes a WD40 protein involved in $18 \mathrm{~S}$ ribosomal RNA biogenesis. Plant Cell 17 (8), 2340-2354. doi: 10.1105/tpc. 105.033563

Shi, Y., Di Giammartino, D. C., Taylor, D., Sarkeshik, A., Rice, W. J., Yates, J. R., III, et al. (2009). Molecular architecture of the human pre-mRNA 3' processing complex. Mol. Cell 33 (3), 365-376. doi: 10.1016/j.molcel.2008.12.028

Shi, H., Wang, X., Mo, X., Tang, C., Zhong, S., and Deng, X. W. (2015). Arabidopsis DET1 degrades HFR1 but stabilizes PIF1 to precisely regulate seed germination. Proc. Natl. Acad. Sci. 112 (12), 3817-3822. doi: 10.1073/ pnas. 1502405112

Shuck, S. C., Short, E. A., and Turchi, J. J. (2008). Eukaryotic nucleotide excision repair: from understanding mechanisms to influencing biology. Cell Res. 18 (1), 64. doi: $10.1038 / \mathrm{cr} .2008 .2$

Simpson, G. G., Dijkwel, P. P., Quesada, V., Henderson, I., and Dean, C. (2003). FY is an RNA $3^{\prime}$ end-processing factor that interacts with FCA to control the Arabidopsis floral transition. Cell 113 (6), 777-787. doi: 10.1016/ S0092-8674(03)00425-2
Singer, R., Atar, S., Atias, O., Oron, E., Segal, D., Hirsch, J. A., et al. (2014). Drosophila COP9 signalosome subunit 7 interacts with multiple genomic loci to regulate development. Nucleic Acids Res. 42 (15), 9761-9770. doi: 10.1093/nar/gku723

Sørensen, B. B., Ehrnsberger, H. F., Esposito, S., Pfab, A., Bruckmann, A., Hauptmann, J., et al. (2017). The Arabidopsis THO/TREX component TEX1 functionally interacts with MOS11 and modulates mRNA export and alternative splicing events. Plant Mol. Biol. 93 (3), 283-298. doi: 10.1007/ s11103-016-0561-9

Spike, C. A., Shaw, J. E., and Herman, R. K. (2001). Analysis of smu-1, a gene that regulates the alternative splicing of unc-52 Pre-mRNA in Caenorhabditis elegans. Mol. Cell. Biol. 21 (15), 4985-4995. doi: 10.1128/MCB.21.15.4985-4995.2001

Stapleton, A. E., and Walbot, V. (1994). Flavonoids can protect maize DNA from the induction of ultraviolet radiation damage. Plant Physiol. 105 (3), 881-889. doi: 10.1104/pp.105.3.881

Sugasawa, K., Okuda, Y., Saijo, M., Nishi, R., Matsuda, N., Chu, G., et al. (2005). UV-induced ubiquitylation of XPC protein mediated by UV-DDB-ubiquitin ligase complex. Cell 121 (3), 387-400. doi: 10.1016/j.cell.2005.02.035

Sun, Z.-W., and Allis, C. D. (2002). Ubiquitination of histone H2B regulates H3 methylation and gene silencing in yeast. Nature 418 (6893), 104. doi: 10.1038/ nature 00883

Suzuki, M., Shinozuka, N., Hirakata, T., Nakata, M. T., Demura, T., Tsukaya, H., et al. (2018). Oligocellula1/high expression of osmotically responsive genes 15 promotes cell proliferation with histone deacetylase 9 and powerdress during leaf development in Arabidopsis thaliana. Front. Plant Sci. 9, 580-580. doi: $10.3389 /$ fpls.2018.00580

Tamura, K., Fukao, Y., Iwamoto, M., Haraguchi, T., and Hara-Nishimura, I. (2010). Identification and characterization of nuclear pore complex components in Arabidopsis thaliana. Plant Cell 22 (12), 4084-4097. doi: 10.1105/tpc. 110.079947

Tevatia, R., and Oyler, G. A. (2018). Evolution of DDB1-binding WD40 (DWD) in the viridiplantae. PLoS One 13 (1), e0190282. doi: 10.1371/journal.pone.0190282

Tuller, T., Diament, A., Yahalom, A., Zemach, A., Atar, S., and Chamovitz, D. A. (2018). The COP9 signalosome influences the epigenetic landscape of Arabidopsis thaliana. Bioinformatics (Oxford, England) 35 (16), 2718-2723. doi: 10.1093/ bioinformatics/bty1053

Ulrich, A. K., Schulz, J. F., Kamprad, A., Schütze, T., and Wahl, M. C. (2016). Structural basis for the functional coupling of the alternative splicing factors Smul and red. Structure 24 (5), 762-773. doi: 10.1016/j.str.2016.03.016

Van Nocker, S., and Ludwig, P. (2003). The WD-repeat protein superfamily in Arabidopsis: conservation and divergence in structure and function. $B M C$ Genomics 4 (1), 50. doi: 10.1186/1471-2164-4-50

Wiborg, J., O'Shea, C., and Skriver, K. (2008). Biochemical function of typical and variant Arabidopsis thaliana U-box E3 ubiquitin-protein ligases. Biochem. J. 413 (3), 447-457. doi: 10.1042/BJ20071568

Xu, L., Ménard, R., Berr, A., Fuchs, J., Cognat, V., Meyer, D., et al. (2009). The E2 ubiquitin-conjugating enzymes, AtUBC1 and AtUBC2, play redundant roles and are involved in activation of FLC expression and repression of flowering in Arabidopsis thaliana. Plant J. 57 (2), 279-288. doi: 10.1111/j.1365-313X.2008.03684.X

Yanagawa, Y., Sullivan, J. A., Komatsu, S., Gusmaroli, G., Suzuki, G., Yin, J., et al. (2004). Arabidopsis COP10 forms a complex with DDB1 and DET1 in vivo and enhances the activity of ubiquitin conjugating enzymes. Genes Dev. 18 (17), 2172-2181. doi: 10.1101/gad.1229504

Yang, J., Lin, R., Sullivan, J., Hoecker, U., Liu, B., Xu, L., et al. (2005). Light regulates COP1-mediated degradation of HFR1, a transcription factor essential for light signaling in Arabidopsis. Plant Cell 17 (3), 804-821. doi: 10.1105/ tpc. 104.030205

Yelina, N. E., Smith, L. M., Jones, A. M., Patel, K., Kelly, K. A., and Baulcombe, D. C. (2010). Putative Arabidopsis THO/TREX mRNA export complex is involved in transgene and endogenous siRNA biosynthesis. Proc. Natl. Acad. Sci. 107 (31), 13948-13953. doi: 10.1073/pnas.0911341107

Zhang, C., Guo, H., Zhang, J., Guo, G., Schumaker, K. S., and Guo, Y. (2010). Arabidopsis cockayne syndrome A-like proteins $1 \mathrm{~A}$ and $1 \mathrm{~B}$ form a complex with CULLIN4 and damage DNA binding protein $1 \mathrm{~A}$ and regulate the response to UV irradiation. Plant Cell 22 (7), 2353-2369. doi: 10.1105/tpc.110.073973

Zhao, S., Tang, H., Yan, D., Fan, J., Sun, H., Wen, Y., et al. (2016). DDA1 promotes stage IIB-IIC colon cancer progression by activating NFKB/CSN2/GSK-3 $\beta$ signaling. Oncotarget 7 (15), 19794. doi: 10.18632/oncotarget.7847 
Zhu, J., Jeong, J. C., Zhu, Y., Sokolchik, I., Miyazaki, S., Zhu, J.-K., et al. (2008). Involvement of Arabidopsis HOS15 in histone deacetylation and cold tolerance. Proc. Natl. Acad. Sci. 105 (12), 4945-4950. doi: 10.1073/pnas.0801029105

Zhu, D., Maier, A., Lee, J.-H., Laubinger, S., Saijo, Y., Wang, H., et al. (2008). Biochemical characterization of Arabidopsis complexes containing constitutively photomorphogenicl and suppressor of phya proteins in light control of plant development. Plant Cell 20 (9), 2307-2323. doi: 10.1105/ tpc.107.056580

Zimmerman, E. S., Schulman, B. A., and Zheng, N. (2010). Structural assembly of cullin-RING ubiquitin ligase complexes. Curr. Opin. Struct. Biol. 20 (6), 714-721. doi: 10.1016/j.sbi.2010.08.010

Zografidis, A., Kapolas, G., Podia, V., Beri, D., Papadopoulou, K., Milioni, D., et al. (2014). Transcriptional regulation and functional involvement of the
Arabidopsis pescadillo ortholog AtPES in root development. Plant Sci. 229, 53-65. doi: 10.1016/j.plantsci.2014.08.012

Conflict of Interest Statement: The authors declare that the research was conducted in the absence of any commercial or financial relationships that could be construed as a potential conflict of interest.

Copyright (c) 2019 Fonseca and Rubio. This is an open-access article distributed under the terms of the Creative Commons Attribution License (CC BY). The use, distribution or reproduction in other forums is permitted, provided the original author(s) and the copyright owner(s) are credited and that the original publication in this journal is cited, in accordance with accepted academic practice. No use, distribution or reproduction is permitted which does not comply with these terms. 